\title{
Connettere spazi tra arti e scienze: scatole proiettive come realtà (analogicamente) aumentata prima e dopo la Realtà (digitalmente) Aumentata
}

\author{
Fabrizio Gay \\ Irene Cazzaro
}

Abstract

Questo contributo espone una nuova interpretazione (storico-tecnica) e alcune riattualizzazioni (progettuali) del tema delle 'scatole prospettiche' realizzate come casi di dispositivi 'anamorfici' nel genere delle 'vedute d'interni' del XVII secolo belga e olandese. Presentiamo le nostre considerazioni come argomento dimostrativo e sperimentale di una tesi più generale concernente la contiguità estetica tra i domini sociali che oggi chiamiamo 'arte' e 'scienza'.

Sosteniamo che questi 'oggetti curiosi' sono dispositivi sperimentali d'esperienza estetica giacché il loro funzionamento induce nello spettatore un processo di successive prese di coscienza dei diversi modi di esistenza (attuale, realizzata, potenziale e virtuale) delle immagini di uno stesso spazio interno. Le relazioni tra la costruzione geometrica di questi dispositivi e le cornici semantiche che si propongono al loro uso ci consentono di sperimentare il loro funzionamento estetico e semiotico attraverso alcune loro reinvenzioni attuali nel campo del displaying.

Nello studio di questa particolare categoria di artefatti visuali abbiamo seguito un metodo 'anacronico': a) analisi filologica degli esemplari esistenti e della loro genealogia essenziale, b) studio del loro dispositivo geometrico, c) studio del loro dispositivo semiotico, d) sperimentazione reale attraverso loro reinvenzioni che ne mettono in luci alcuni aspetti attualizzanti e consentono una dimostrazione in vivo delle ipotesi interpretative.

Parole chiave

storia della rappresentazione, teoria delle immagini, scatole proiettive, displaying, didattica della geometria descrittiva.

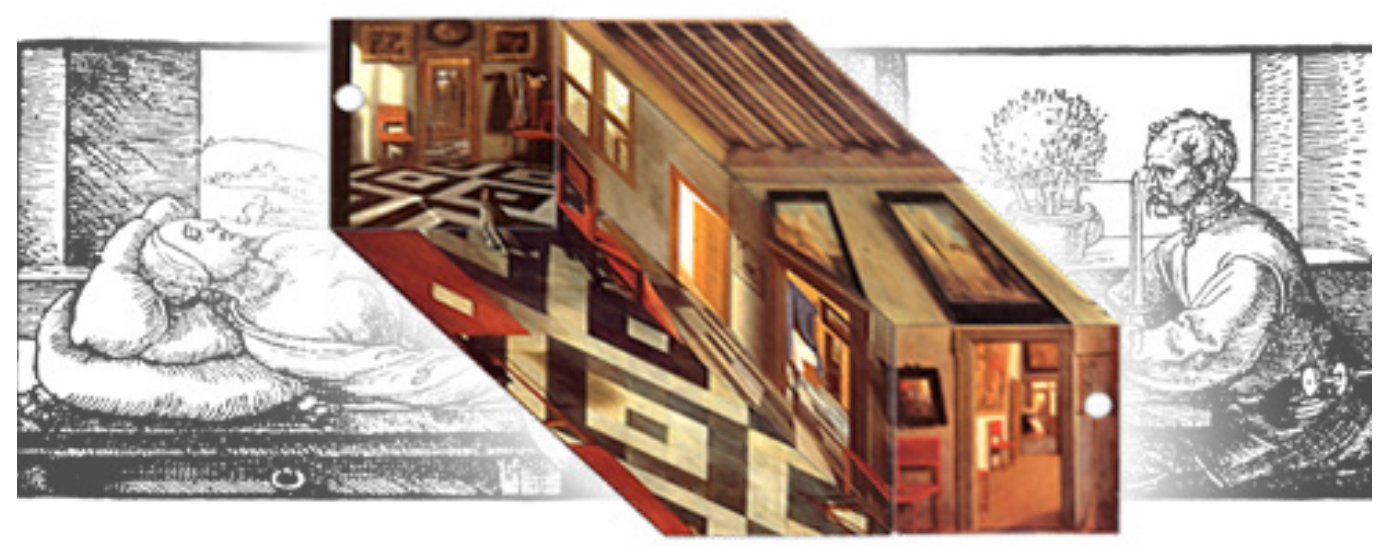




\section{Una teoria in atto: oggetti prospettici e omologie proiettive 'di fatto'}

Ha ragione chi - come già Pavel Florenskij [1990] - sostiene che l'avvento della prospettiva rinascimentale ha comportato un impoverimento della spazialità figurativa vincolandola in un solo punto di vista monoculare. Ma sarebbe oltremodo ingiusto confondere la prospettiva rinascimentale con il fenomeno da baraccone del trompe-l'œil, ignorando l'autonomia dello spazio figurato nell'oggetto prospettico, la sua forza espressiva e la virtuale dinamica del punto di vista che gli artisti vi hanno saputo rendere.

Parliamo di 'oggetto prospettico' - e non solo di 'quadri' o di 'immagini piane' - anzitutto perché vogliamo riguardare anche le pitture nell'intera e concreta scena pratica e spaziale del loro uso concreto, cioè nel modo in cui esse stabiliscono un rapporto tra lo spazio-tempo figurato e quello realmente esperito dall'osservatore, un rapporto che solo raramente degenera nel trompe-l'œil. L'oggetto prospettico - cioè la figurazione prospettica bi o tridimensionale con il suo luogo e pratica d'uso - è un artefatto visuale che si evolve parallelamente alla teoria matematica della prospettiva, ai dispositivi prospettografici e ottici, alla spazialità teatrale, domestica e liturgica, nonché agli artefatti anamorfici e al loro uso ostensivo nelle wunderkammern rinascimentali e barocche.

La prima assunzione della nostra tesi è che, fin dal primo Quattrocento, la teoria della prospettiva lineare nacque subito tutta intera, come una 'geometria in atto', sia i) nella sua adeguatezza a dar conto della fenomenologia visiva, sia ii) nella sua coerenza geometrica-proiettiva.

Fig. I.Tre visualizzazioni della pagina del $\mathrm{De}$ prospectiva pingend $(1472-5)$, L. XXIX Biblioteca Panizzi, Reggio Emilia, Mss. Regg. A 41/2 (Piero, 2017) -, nella quale Piero della Francesca esemplifica la costruzione geometrica della pianta prospettica di un edificio ottagonale: "Nel piano degradato la superficie di un fondamente di un edifizio de octo face dato derro d". "Per " dezid" ". Per "degradazione "lautore intende prospettiva: un metodo di prospettiva. un metodo corretta trasformazion proiettiva di una figura piana (un quadrato) a partire dalla sua vera forma e dalla distanza di osservazione, costruzione probabilmente già in uso nella pratica artistica: Leon Battista Alberti, Elementa picturae, I 864. Si mostra come questa costruzione presupponga costruzione presupponga 'individua ribaltondo sindividua ribaltando punto di vista $O$ sul piano della rappresentazione, trasformando la prospettività di centro $\bigcirc$ tra $\pi \mathrm{e}$ $\pi$ ' nell'omologia di centro 0 su $\pi$ ' $[O \approx$ Centro della prospettività; $\bigcirc^{*} \approx$ Centro dell'omologia in $\pi^{\prime} ; O^{\prime} \approx$ Punto limite; $\left.\right|^{\prime} \approx$ Retta limite; $u \equiv u^{\prime} \approx$ Asse dell'omologia] secondo i due teoremi di Simon Stevin [Stevin 1608, pp 16-20].

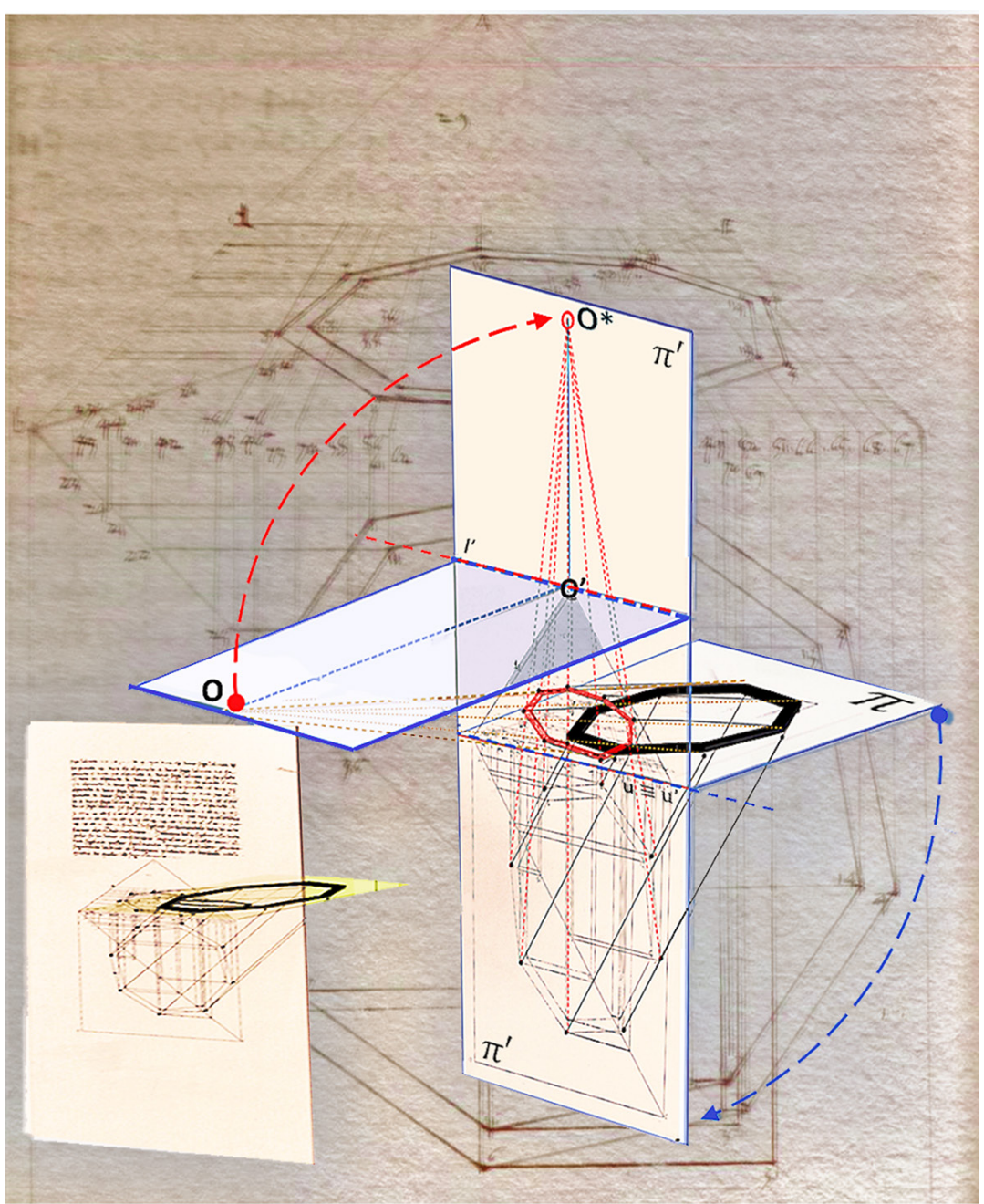


Fig. 2. a). Quadrato semiotico della veridizione (qui nel senso di 'verosimiglianza') in rosso segnato 'schema della manifestazione' (non manifestazione' (non sembrare $\leftrightarrow$ sembrare) 1972, p. 32 e p. 419].

). Due assiologie di J.M Foch: al centro, l'assiologia dei valori di consumo, in periferia, l'assiologia de modi di valorizzazione del percorso spaziale di un viaggiatore [Floch 990] i) L'adeguatezza della prospettiva a surrogare la visione diretta monoculare era stata dimostrata anzitutto attraverso le celebri tavolette prospettiche di Brunelleschi che, entro il secondo decennio del XV secolo, erano note sia come opere d'arte (alto artigianato), sia come prototipi di quelle che oggi chiameremmo 'dimostrazioni scientifiche'.

ii) Nel successivo mezzo secolo si attesta anche la piena coerenza interna del disegno in prospettiva riferito sul fatto che - come dimostrano evidentemente i suoi primi grafici esplicativi (fig. I) - la sua costruzione dipendeva dalla trasformazione di semplici figure piane, ovvero, dal tracciamento di quelle che oggi diremmo 'prospettività piane sul quadro', cioè, da 'omologie del piano', per quanto non si può fare un uso esplicito del 'centro dell'omologia', ma solo degli elementi limite (punti e rette di fuga) e degli elementi uniti.

L'idea che il centro dell'omologia costruttiva della prospettiva di un poligono non fosse che il suo 'punto di vista' ribaltato sul quadro intorno alla traccia di un piano proiettante (fig. I) era già embrionalmente contenuta nella 'costruzione abbreviata' di Alberti e fu completamente chiarita da Simon Stevin [ 1605] in forma di teorema.

II teorema di Stevin ci riporta alla constatazione storica che soprattutto in ambiente fiammingo e olandese [Wheelock 1973], specie nel genere della veduta interna del XVII secolo, la teoria prospettica si evolve incrociando i suoi tre versanti: I'adeguatezza ottica, la coerenza geometrica e l'invenzione di nuovi artefatti visuali. Ci riferiamo alle 'scatole prospettiche' oggi note in sei esemplari che hanno le dimensioni di un mobile d'arredo - appena un po' più piccolo degli analoghi e tipici 'cassoni matrimoniali' dipinti - come se fossero modelli di scenografie domestiche.

Oggetti ibridi tra la pittura su tavola e la prospettiva in rilievo, queste 'scatole' di tavole pittoriche sono coerenti 'prospettive di prospettive' che mostrano anamorficamente un interno sulle facce di un prisma ma con una verosimiglianza luminosa e atmosferica mai raggiunta prima in pittura. Esse impongono l'evidenza di questa verosimiglianza 'atmosferica' rendendola ulteriormente sperimentabile dal fatto che offrono a uno spettatore in movimento lo spettacolo di un interno (figurato) in un interno (reale), cioè in condizioni luministiche analoghe ed entro cornici semantiche fisicamente paragonabili. (a)

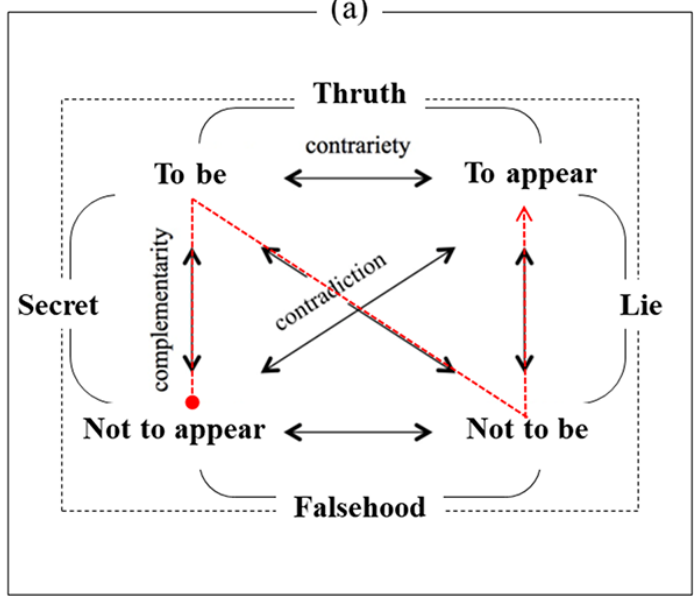

(b)

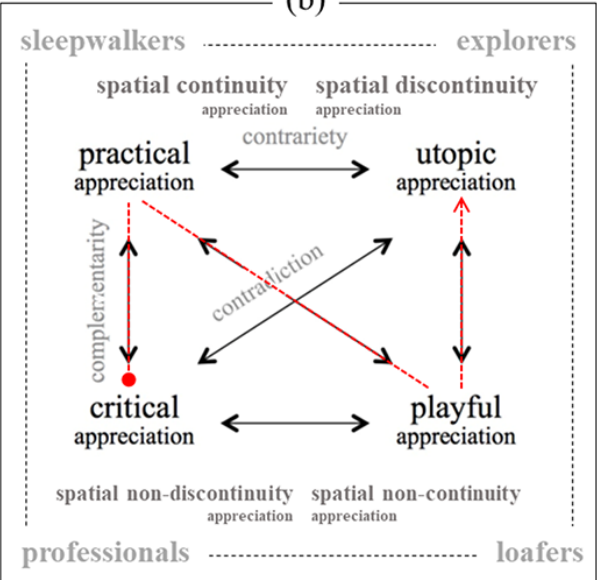

I percorsi cognitivi dello spettatore e del pittore: stadio delle prospettività e stadio della prospettiva

Questi oggetti [meta]prospettici d'arredo olandesi - appartenendo alla genealogia delle anamorfosi rinascimentali e barocche - si prestano al classico schema d'uso delle anamorfosi che prevede diverse posizioni spaziali del punto vista dell'osservatore: alcune 'corrette' o 'decettive', altre progressivamente deformate, 'in accomodamento' o 'in adeguazione'. Questi valori di 'correttezza' o di 'decezione', di 'casualità' o di 'necessità', dipendono dalle plausibili cornici semantiche della concreta scena d'uso dell'oggetto anamorfico. 
a) Percorso dello spettatore - L'ampia storiografia sulla quadratura anamorfica concorda almeno sulla processualità dello spettacolo dell'emergere e dello scomparire delle forme nella percezione dell'osservatore transitante lungo i suoi percorsi possibili; inoltre, per lo più, assegna a tale processo il senso di una progressiva presa di coscienza dello spettatore, secondo un fine catartico o, talora, pedagogico. Nel caso delle scatole prospettiche d'interno domestico olandese possiamo semplificare questo schema distinguendo anzitutto i due (tipici) stadi opposti: $I^{\circ}$ ) quello (durativo) in cui lo spettatore vede l'oggetto d'arredo in quanto tale cogliendovi una qualche forma di rappresentazione pittorica coerentemente 'distorta', $2^{\circ}$ ) quello (perfettivo) in cui lo spettatore situatosi nei punti di vista 'corretti' gode di una vista fenomenicamente verosimile (decettiva) dellinterno rappresentato. Definiamo

Fig. 3. Rappresentazione in proiezioni ortogonali e in sviluppo piano di una scatola cubica OUXYZ con l'immagine $\pi$ ' proiettata $d$ O sul triedro trirettangolo UXYZ. O $\approx$ Centro delle tre prospettività tra $\pi^{\prime}$ e $U X Y, \pi^{\prime}$ e $U X Z, \pi^{\prime}$ e UYZ $\mathrm{d} \approx$ distanza principale; $\pi \approx$ piano parallelo anteriore: $X^{*} Y^{*} Z * \approx$ sviluppo piano di UXYZ; $\left(\pi^{\prime} \cup X Y Z\right)^{*} \approx$ svolgimento del trilatero svolgimento del trlatero Per esempi di realizzà. si veda fig. 8 .

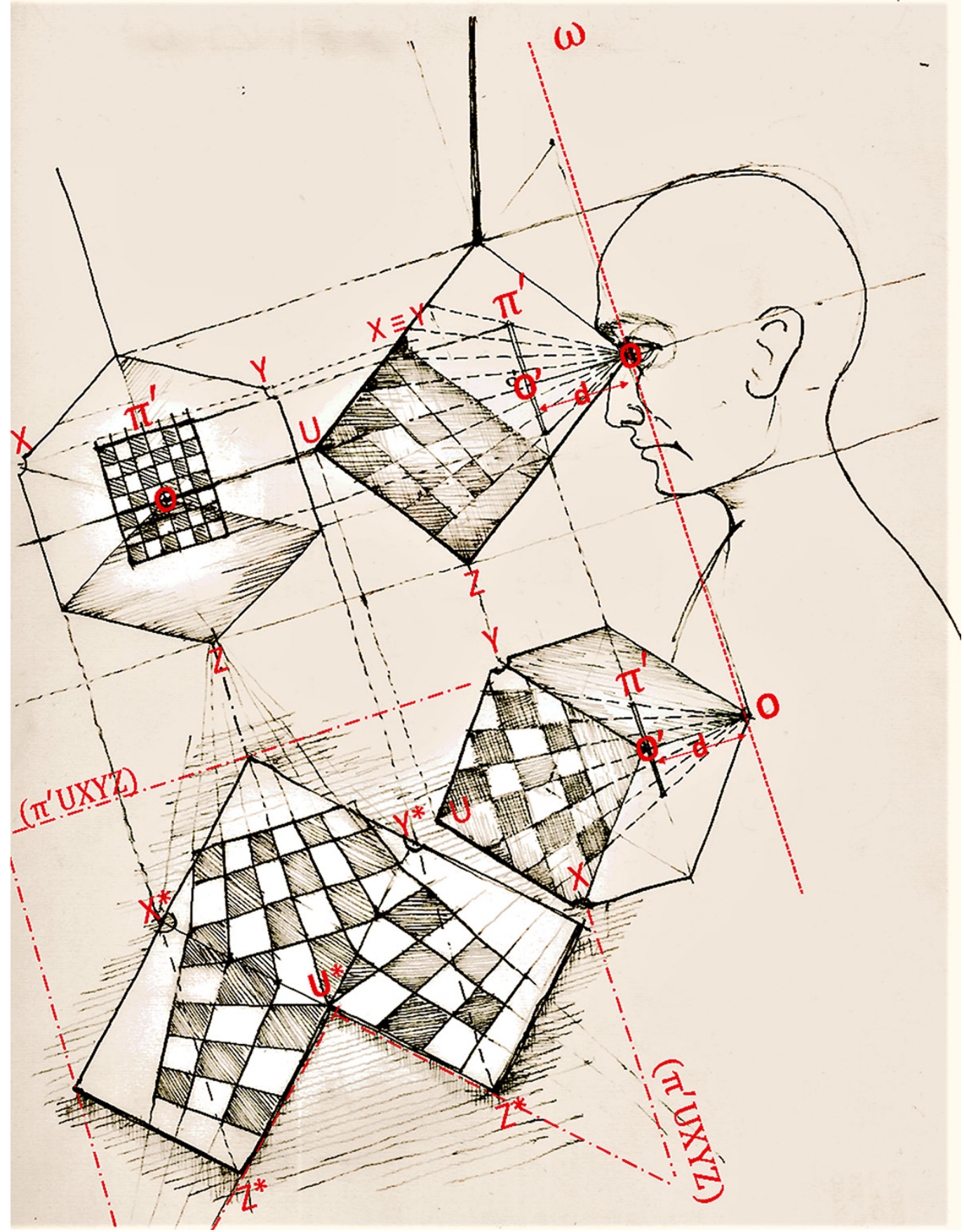


Fig. 4. Scatola prospettica di Pieter Janssens, olio su tavole, $84 \times 82 \times 42 \mathrm{~cm}$, (c. I660-80), Den Haag, Museum Bredius:

a) ricostruzione dell'immagine paradossale di partenza con indicazione del circolo di distanz b) sviluppo piano delle

tre facce interne;

c) sovrapposizione

dell'immagine di partenza alla scatola;

d) scatola prospettica in assonometria ortogona d) interno referente.

Fig. 5. Scatola prospettica di Samuel van Hoogstraten, olio su tavole, 58 $80)$ × $60.5 \mathrm{~cm},(\mathrm{c.} 1655-$ $60)$, London, National Gallery:

a) assonometria ortogonale isometrica svolta delle facce esterne;

b) assonometria svolta delle facce interne:

c) ricostruzione di una delle immagini paradossai di partenza per la vista frontale.
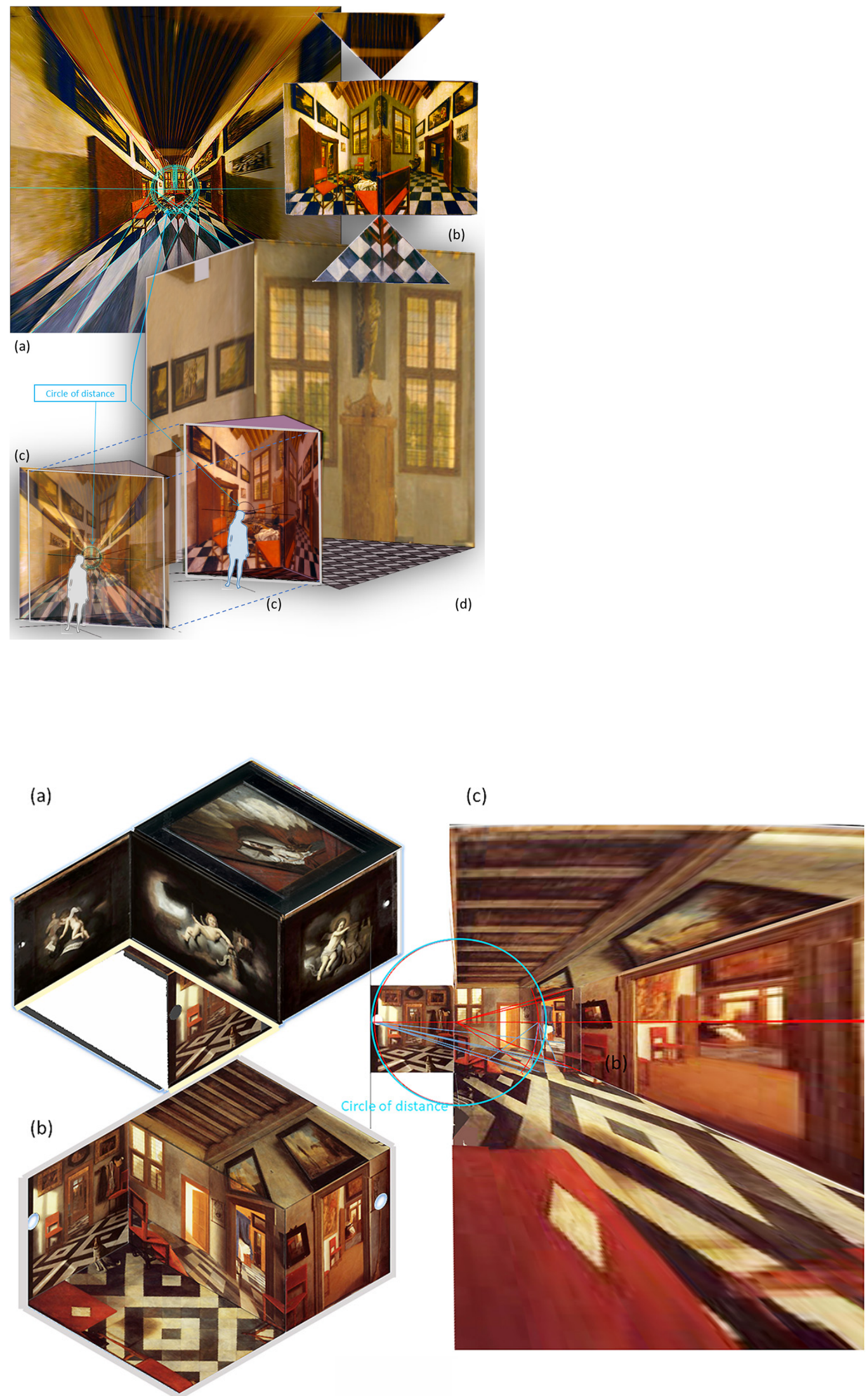
il primo stadio come quello della 'prospettività' giacché lo spettatore vede in modo binoculare la pittura di ogni faccia della scatola come deformata e autonoma, non collimante con le altre. In questa condizione l'eventuale contenuto rappresentativo delle pitture è relegato in un'esistenza virtuale rispetto al concreto spazio di referenza. Solo quando, ponendo un occhio solo nella posizione prevista, egli giunge a cogliere la collimazione visuale tra diverse pitture, entra nel secondo stadio cognitivo: quello della 'prospettiva' vera e propria. Ė solo allora che lo spettatore - per la posizione forzatamente collocata ed esclusivamente monoculare - realizza lo spettacolo (decettivo) dell'interno figurato e relega lo spazio 'reale' in un'esistenza 'virtuale' rispetto allo spazio visivamente esperito, stante ora una discrasia tra lo 'spazio ottico' e gli altri spazi sensoriali nella coscienza dello spettatore, come direbbe Florenskij [Florenskij 2007, pp. 27I -273]. L'essenziale del tipico spettacolo offerto da questi dispositivi è riassumibile con due schemi classici della teoria semiotica di tradizione greimassiana. Essi mostrano che (fig. 2 a) nella fase durativa (I) l'oggetto anamorfico è valutato come latore di un 'segreto' che porta alla 'concreta' e 'falsata' rappresentazione di un interno,

Fig. 6. a) Albrecht Dürer, incisione illustrative di un dispositivo prospettografico, 1525;

b) Marcel Duchamp, Etant donnés: $1^{\circ}$ la chute d'eau, $2^{\circ}$ le gaz d'éclairage, installazione ambientale, $242.6 \times 1778 \times 1245$ $242.6 \times 1947.866)$ (24.5 (1) delphia M
Filadelfia;

c) Schema dell'istallazione [Lyotard 2010].
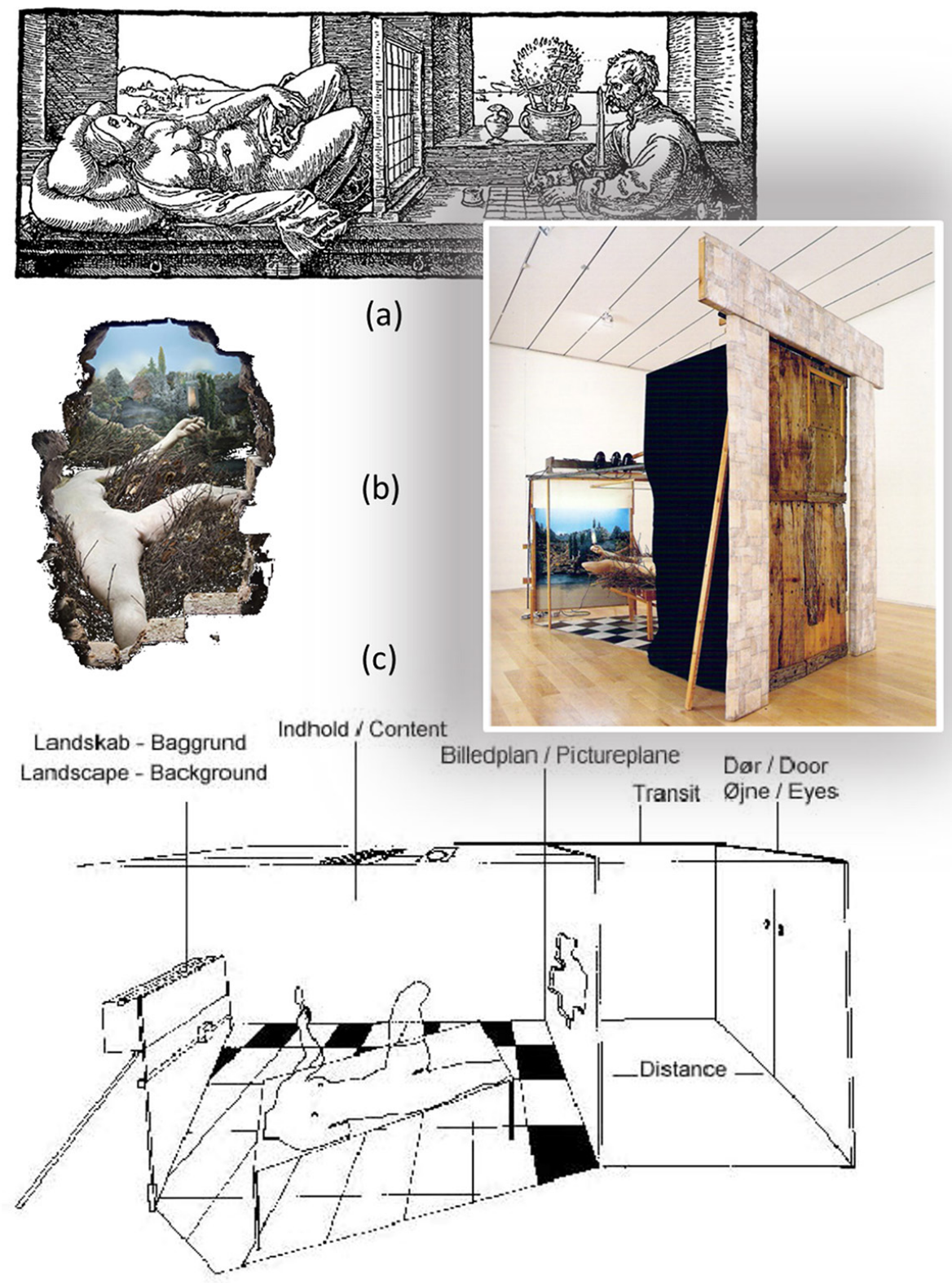
rappresentazione che si rivela poi 'illusoria' e, infine, 'verosimile' nella fase decettiva (2), dimostrando una sua 'verità' in rapporto a uno spazio di referenza virtuale. Nel processo di accomodamento del punto di vista lo spazio dell'interno reale può essere diversamente valorizzato (fig. 2 b) trasformando le attitudini e il ruolo dello spettatore che passa dall'esplorazione (critica) dello spazio reale a quella (partecipata) dello spazio virtuale rappresentato. Il quadrato semiotico rappresenta bene la natura ciclica di questi processi analoghi, per certi versi, a un fenomeno di 'isteresi'.

b) Percorso del pittore -Verosimilmente, la costruzione di una scatola prospettica presuppone una tecnica tipica della quadratura anamorfica (fig. 3): parte da un disegno prospettico complessivo e giunge alla sua proiezione su almeno tre facce distinte, cioè, almeno tre 'prospettività' di una stessa 'prospettiva'. Le condizioni geometriche della costruzione corretta sono due: $1^{\circ}$ ) la coerenza delle prospettività e $2^{\circ}$ ) la verosimiglianza della resa di profondità prospettica [White 197I], adottando una 'distanza principale' compatibile con quella del punto di vista obbligato. La prospettiva di partenza è una veduta di fatto 'paradossale' giacché ricade quasi totalmente fuori del corretto circolo di distanza compatibile con il punto di vista designato (figg. 4, 5). Praticamente, la proiezione di questo disegno di partenza poteva avvenire fisicamente, ricalcando l'ombra di un reticolo di fili - analogo a quello del disegno preparatorio - proiettata sulle facce della scatola da un lume posto nell'unico centro delle
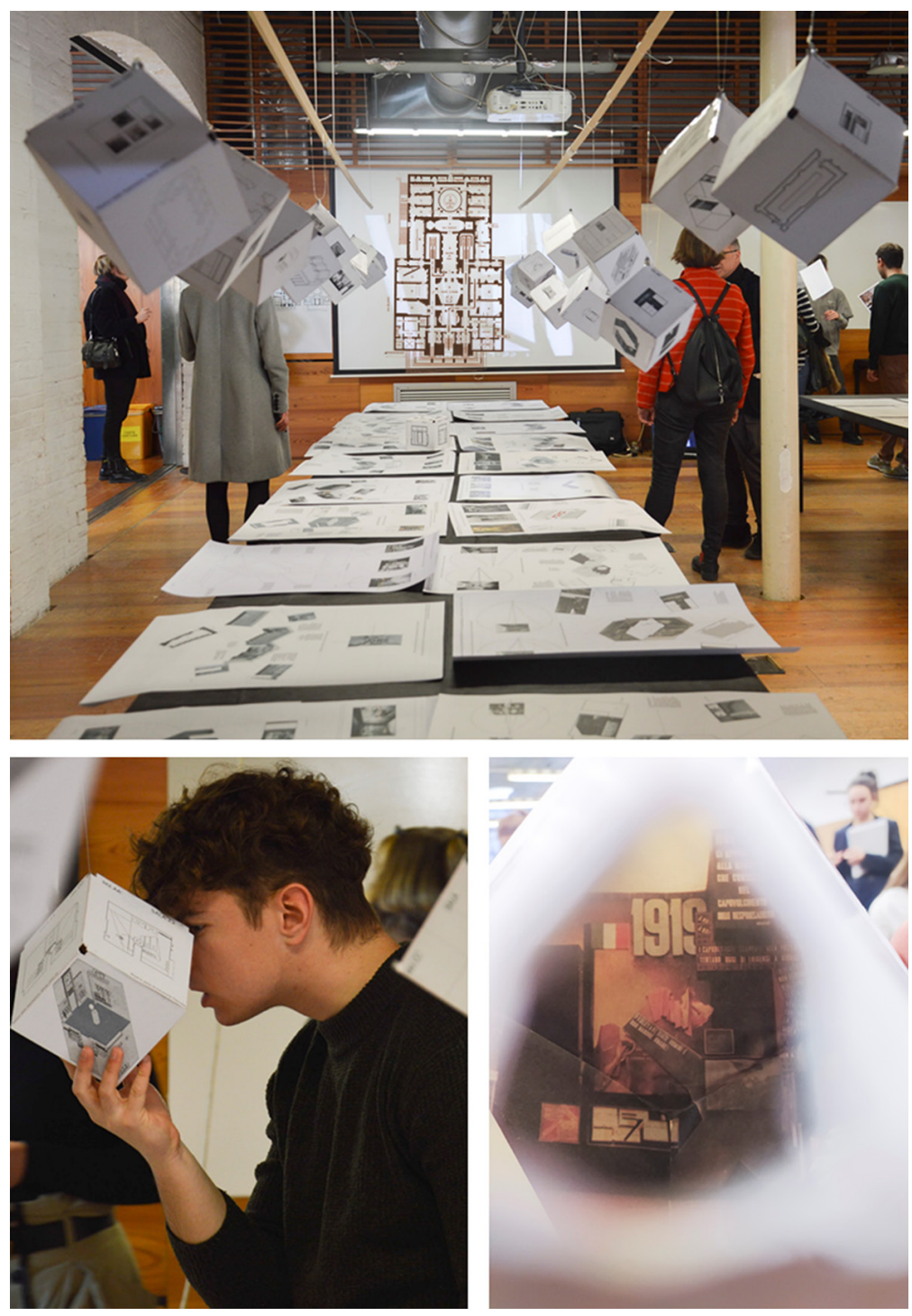
(a)

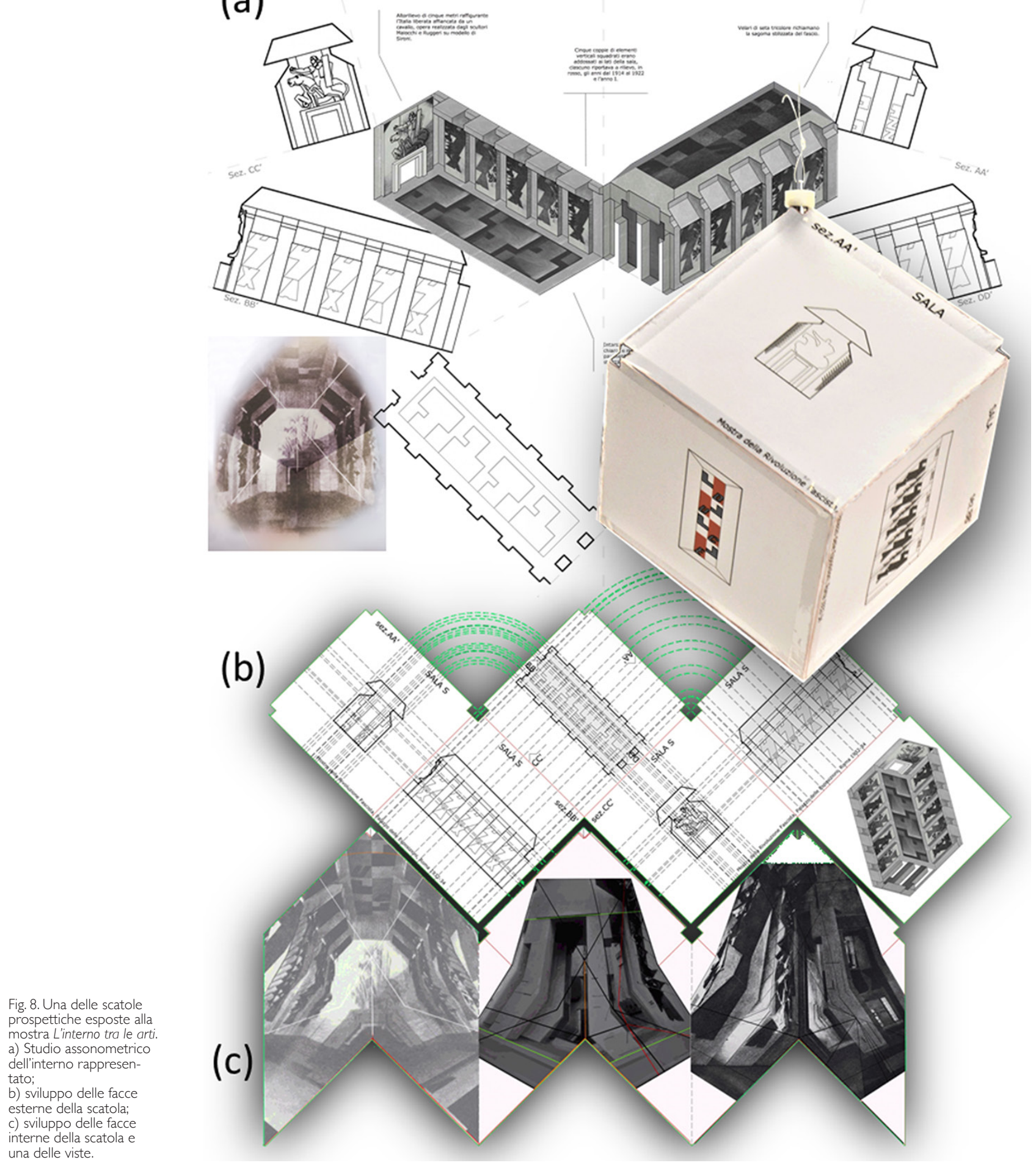


Fig. 9. Caleidoscopio percorribile in un angolo del giardino Barovier a Murano, fotografia del primo modello.

Fig. 10. Pianta e alzato del caleidoscopio fig. 9 planimetria delle spazio percorribile; sullo sfondo planimetria dello spazio visibile nella mise en abyme.
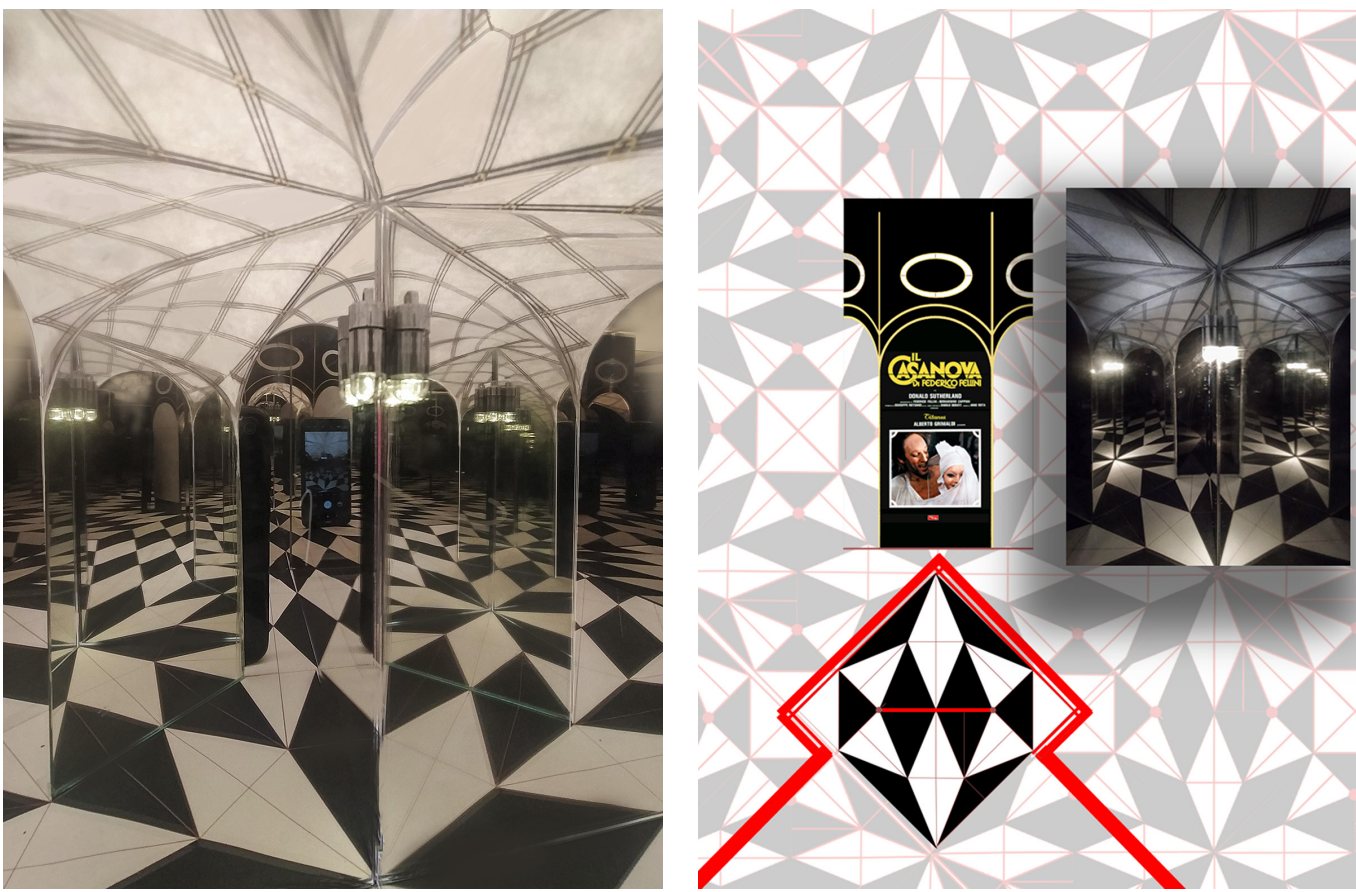

diverse prospettività. Ma questo procedimento pratico è realizzabile solo nei casi in cui il punto di vista è, anche se di poco, esterno alla scatola (fig. 4). Almeno un caso - dei sei oggi noti - (fig. 5) ricade solo parzialmente in questa condizione giacché due dei tre punti di 'visione corretta' predisposti da van Hoogstraten eccedono la 'distanza principale' adottata nella costruzione prospettica delle loro vedute. David Bomford [ Bomford et al. 1987] ritiene che la costruzione del coordinamento prospettico delle vedute sia avvenuta empiricamente, stante anche il fatto - giusta l'osservazione di Joyce Plesters [Brown et al. 1987] - che van Hoogstraten non la spiega nella pagine del suo trattato postumo del 1678 [Hoogstraten 1969]. Restano ancora da vagliare le ipotesi d'integrazione della scatola di van Hoogstraten, custodita alla Nation Gallery, con opportuni dispositivi catottrici capaci di collocare il punto di vista in un oggetto prospettico fatto per de-automatizzare la visione quotidiana giocando su un fenomeno di straniamento e riappaesamento dell'osservatore. In ogni caso sembra che il percorso del pittore e dell'osservatore - dallo stadio delle prospettività a quello della prospettiva - coincidano ma seguendo versi opposti.

\section{II 'movente' dello sguardo in interno}

Una parte della letteratura sull'interpretazione iconografica della veduta d'interni domestici olandese ne individua il 'topic' (tema) nella narrazione di eventi domestici in forma di breve sceneggiatura di situazioni stereotipate. Ma le facce esterne delle scatole prospettiche aggiungono talora una veste allegorica che complica l'attribuzione di proprietà semantiche ad alcuni oggetti figurati. Questa convergenza di 'allegoria' e 'interno spiato' mette in luce il 'motivo' della 'seduzione' e l'isotopia 'erotica' - frequente nei dipinti olandesi del XVII secolo [Koslow 1967;Woodall 1996] - che conferisce allo spettatore il ruolo tematico del voyeur (fig. 2 b). Questo - secondo alcuni studi come quelli di Susan Koslow [Koslow 1967] - sembra evidente nella citata scatola della National Gallery, nelle cui rappresentazioni interne sono disseminati oggetti come un cuscino, un pettine, una collana di perle, che conducono a una donna probabilmente sedotta dal suo visitatore. Herman Colenbrander [Colenbrander 20 I3] paragona invece quella scatola alle altre tre che rappresentano interni domestici e conclude che sono presenti in prevalenza i due temi morali della vanitas e della scelta tra vizio e virtù, in rappresentazioni di nature morte con modeste colazioni che erano spesso 


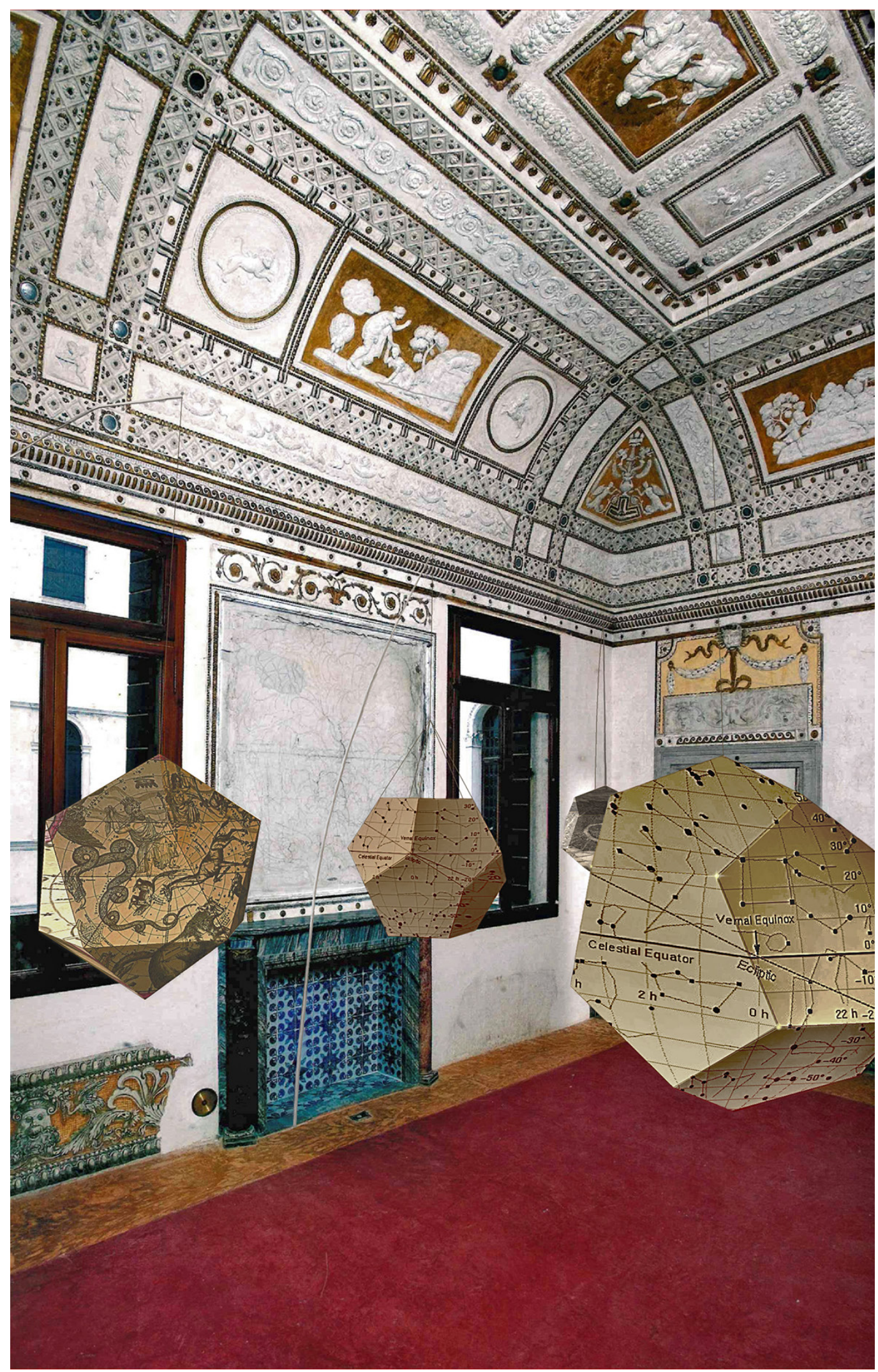


parte di regali nuziali e ci porterebbero di nuovo a pensare ai cassoni matrimoniali. Celeste Brusati [Brusati 1995; Brusati 20 I3], invece, dopo aver riconosciuto la presenza significativa dell'elemento erotico, privilegia comunque l'importanza che doveva avere la scatola nel mostrare i risultati raggiunti nella realizzazione di prospettive. In particolare, sono le cornici simulate, presenti in molte opere di van Hoogstraten, un elemento fondamentale in quanto espressione della dualità del dipinto: da una parte oggetto materiale, dall'altra rappresentazione: precisamente, 'rappresentazione di una rappresentazione' che funziona secondo il ciclo che abbiamo indicato (fig. 2). Perciò le scatole proiettive (prospettive o catottriche) sono artefatti visuali che s'iscrivono nella genealogia che passa per le svariate forme di peepshow e per le loro reinvenzioni artistiche contemporanee: per esempio, dall'istallazione che Marcel Duchap ha intitolato Étant Donnés: $1^{\circ}$ la chute d'eau, $2^{\circ}$ le gaz d'éclairage... (fig. 6) al film Paris, Texas di Wim Wenders.

\section{Conclusioni pratiche: tre dei modi dell'interno in interno}

Le scatole proiettive (prospettive e catottriche) sono oggetti 'sfaccettati' anche dal punto di vista semantico. Per studiare aspetti di questa 'sfaccettatura semantica' ne abbiamo progettate altre destinate a situazioni tipiche del displaying contemporaneo, rubricando ciò che abbiamo chiamato 'il movente dello sguardo' secondo le succitate (fig. 2 b) assiologie di Floch. a) Valorizzazione critica e pratica: un dispositivo didattico.

Nell'occasione della mostra di una mostra (fig. 7) - la mostra didattica di uno studio grafico della Mostra delle Rivoluzione Fascista al Palazzo delle Esposizioni di Roma del 1932-1934 - abbiamo ideato scatole prospettiche cubiche ciascuna delle quali, avvicinata a un grafico analitico a stampa, espone la ricostruzione per fotomodellazione di una sala della Mostra. Sulle facce esterne di ogni cubo (fig. 8) sono correttamente collocate le rappresentazioni di una stanza in proiezione ortogonale secondo l'effettiva giacitura reciproca dei piani di rappresentazione (fig. 8 b). Sulle facce interne, visibili dai fori nei tre vertici superiori, sono stampate anamorficamente (fig. 8 c) le fotografie storiche servite alla ricostruzione. La costruzione dell'anamorfosi ha tenuto conto dell'orientamento interno calcolato sulla foto, inoltre il foro di visione è collocato esattamente nel centro focale della presa fotografica originale; dunque la vista monoculare dell'interno risulta pienamente decettiva, diremmo, in 'realtà virtuale', per quanto l'oggetto sia fatto di carta, internamente illuminato da un led.

b) Valorizzazione ludica: un angolo di compulsione caleidoscopica.

Con un caleidoscopio fisicamente attraversabile dallo spettatore (figg. 9, I0) allestito in un giardino muranese abbiamo cercato di restituire l'atmosfera onirica di un set a pianta ottagonale del Casanova di Fellini (1976): quello della scena dell'incontro del seduttore con la monaca Maddalena nell'isola veneziana di San Bartolo, compiaciuti d'esser spiati dall'abate de Bernis attraverso un foro occultato nell'occhio di un pesce dipinto sulla parete dell'alcova. Evidentemente questo set s'iscrive nella variegata genealogia dei peepshow e traducendolo dal cinema a una scatola catottrica se ne amplificano alcuni effetti di senso (fig. I0).

c) Valorizzazione mitica: allegorie in cerca di soggetti.

Nella cinquecentesca Stanza di Callisto di Palazzo Grimani a Venezia (fig. I I) abbiamo proposto una variazione sul tema dell'Étant Donnés di Duchamp. Si tratta di poliedri platonici in carta a doppia faccia, segnati da immagini grafiche storiche: all'esterno si tratta di mappe delle costellazioni zodiacali e vedute topografiche topologicamente adattate al poliedro; all'interno si tratta di incisioni a soggetto erotico derivate da I Modi pubblicati da Marcantonio Raimondi dal 1524, correttamente visibili - giacché proiettivamente adattate - attraverso spioncini collocati in alcuni vertici. Queste immagini di spazi opposti dialogano con i temi astrologici e mitologici della decorazione del soffitto, ma realizzano un cortocircuito iconografico tra generi considerati alti e infimi, assecondando la cornice ironica segnata da un'ode coeva di Francesco Berni (fig. 12). 


\section{XI}

\section{CAPITOLO DELL'ORINALE}

Chi non ha molto ben del naturale et un gran pezzo di conoscimento

3 non può saper che cosa è l'orinale, né quante cose vi si faccin drento (dico senza il servigio dell'orina),

6 che sono ad ogni modo presso a cento; e se fusse un dottor di medicina che le volesse tutte quante dire,

9 arìa facende insino a domattina. Pur, chi qual cosa ne volesse udire, io son contento, per fargli piacere,

12 tutto quel ch'io ne so di diffinire.

E prima inanzi tratto è da sapere che l'orinale è a quel modo tondo

15 acciò che possa più cose tenere: è fatto proprio come è fatto il mondo, che, per aver la forma circulare,

18 voglion dir che non ha né fin né fondo; questo lo sa ogniun che sa murare e che s'intende dell'architettura che insegna altrui le cose misurare. Ha gran profondità la sua natura, 


\section{Riferimenti bibliografici}

Alberti Leon Battista (I 864). Gli elementi di pittura. Cortona: Bimbi. Trad. dal manoscritto originale latino [1 435-'6] Elementa picture. Biblioteca statale di Lucca, ms. 1448.

Berni Francesco (2002). Rime. Milano: Mursia.

Brown Christopher et al. (1987). Samuel van Hoogstraten: Perspective and Painting. In National Gallery Technical Bulletin, vol. II, pp. 60-85.

Brusati Celeste (1995). Artifice and Illusion: The Art and Writing of Samuel Van Hoogstraten. Chicago; London:The University of Chicago Press.

Brusati Celeste (2013). Paradoxical Passages:The Work of Framing in the Art of Samuel van Hoogstraten. In Thijs Weststeijn. Universal Art of Samuel van Hoogstraten (1627-1 678). Amsterdam: Amsterdam University Press, pp. 53-76.

Colenbrander Herman (2013). A Pledge of Marital Domestic Bliss: Samuel van Hoogstraten's Perspective Box in the National Gallery, London. In Thijs Weststeijn. Universal Art of Samuel van Hoogstraten (I 627- I678). Amsterdam: Amsterdam University Press, pp. I39-159.

Dürer Albrecht (1525). Unterweisung der Messung mit dem Zirkel und Richtscheit in Linien, Ebenen und ganzen Corporen. Nürnberg: H. Andreae.

Floch Jean-Marie (1990). Sémiotique, marketing et communication: sous les signes, les stratégies. Paris: Presses Universitaires de France.

Florenskij Pavel Aleksandrovič (1990). La prospettiva rovesciata. Roma: Gangemi Editore.

Florenskij Pavel Aleksandrovič (2007). Lo spazio e il tempo nell'arte. Milano: Adelphi.

Greimas Algirdas Julien, Courtés Joseph (1979). Sémiotique: dictionnaire raisonné de la théorie du langage. Tome I. Paris: Classiques Hachette.

Hoogstraten Samuel van (1969) [1674]. Inleyding tot de hooge schoole der schilderkonst. Utrecht: Dawaco.

Koslow Susan (1967). De Wonderlijke Perspectyfkas: An Aspect of Seventeenth Century Dutch Painting. In Oud-Holland, 82, pp. 35-56.

Lyotard Jean-Francois (2010) [1977]. Les Transformateurs Duchamp = Duchamp's TRANS/Formers. Leuven: Leuven University Press.

Della Francesca Piero (2017) [1472]. De Prospectiva pingendi. Roma: Istituto Poligrafico e Zecca dello Stato.

Stevin Simon (1605). Wisconstige gedachtenissen: inhoudende t'ghene daer hem in gheoeffent heeft den ... Maurits, Prince van Oraengien ... [online]. Tot Leyden: Inde druckerye van lan Bouwensz. (c) $2010 \mathrm{dbnl}$. <https://www.dbnl.org/tekst/ stev00 I wisc03_0l/stev00 I wisc03_0l.pdf>.

Wheelock Arthur K. (1973). Carel Fabritius: Perspective and Optics in Delft. In Nederlands kunsthistorisch jaarboek / red. A.W. Byvanck [u.a.], 24, pp. 63-83.

White John (197I). Nascita e rinascita dello spazio pittorico. Milano: il Saggiatore.

Woodall Joanna (1996). Love Is in the Air - «Amor» as Motivation and Message in Seventeenth-Century Netherlandish Painting. In Art History, 2, 19, pp. 208-246.

\section{Autori}

Fabrizio Gay, Università IUAV di Venezia, degli Studi di Napoli Federico II, fabrizio@iuavit

Irene Cazzaro, Alma Mater Studiorum Università di Bologna, irene.cazzaro2@unibo.it

Per citare questo capitolo: Gay Fabrizio, Cazzaro Irene (2020). Connettere spazi tra arti e scienze: scatole proiettive come realtà (analogicamente) aumentata prima e dopo la Realtà (digitalmente) Aumentata/Connecting spaces between art and science: projective boxes as (analogical') augmented reality before and after the (digital) Augmented Reality. In Arena A., Arena M., Brandolino R.G., Colistra D., Ginex G., Mediati D. Nucifora S., Raffa P. (a cura di). Connettere. Un disegno per annodare e tessere. Atti del $42^{\circ}$ Convegno Internazionale dei Docenti delle Discipline della Rappresentazione/Connecting. Drawing for weaving relationships. Proceedings of the 42 th International Conference of Representation Disciplines Teachers. Milano: FrancoAngeli, pp. 485-510. 


\title{
Connecting Spaces between Art and Science: Projective Boxes as (Analogical) Augmented Reality Before and After the (Digital) Augmented Reality
}

\author{
Fabrizio Gay \\ Irene Cazzaro
}

\section{Abstract}

This paper exposes a new (historico-technical) interpretation and some (planning) updates related to the theme of the 'perspective boxes', created as cases of 'anamorphic' devices pertaining to the genre of the 'interior views' in the Belgian and Dutch 17th century. We present our considerations as a demonstrative and experimental topic of a more general thesis concerning the aesthetic contiguity between the social domains that we now call 'art' and 'science'. We argue that these 'curious objects' are experimental devices generating aesthetic experience since their functioning induces in the spectator a process of subsequent awareness of the different modes of existence (actual, realised, potential and virtual) of the images of a single internal space. The relationships between the geometric construction of these devices and the semantic frames that are proposed for their use allow us to experience their aesthetic and semiotic functioning through some of their current reinventions in the field of displaying.In the study of this particular category of visual artefacts we have followed an 'anachronical' method: a) philological analysis of the existing specimens and their essential genealogy, b) study of their geometric device, c) study of their semiotic device, d) real experimentation through their reinventions that highlight some actualising aspects and allow an in vivo demonstration of the interpretative hypotheses.

Keywords

history of representation, theory of images, projective boxes, displaying, didactics of descriptive geometry.

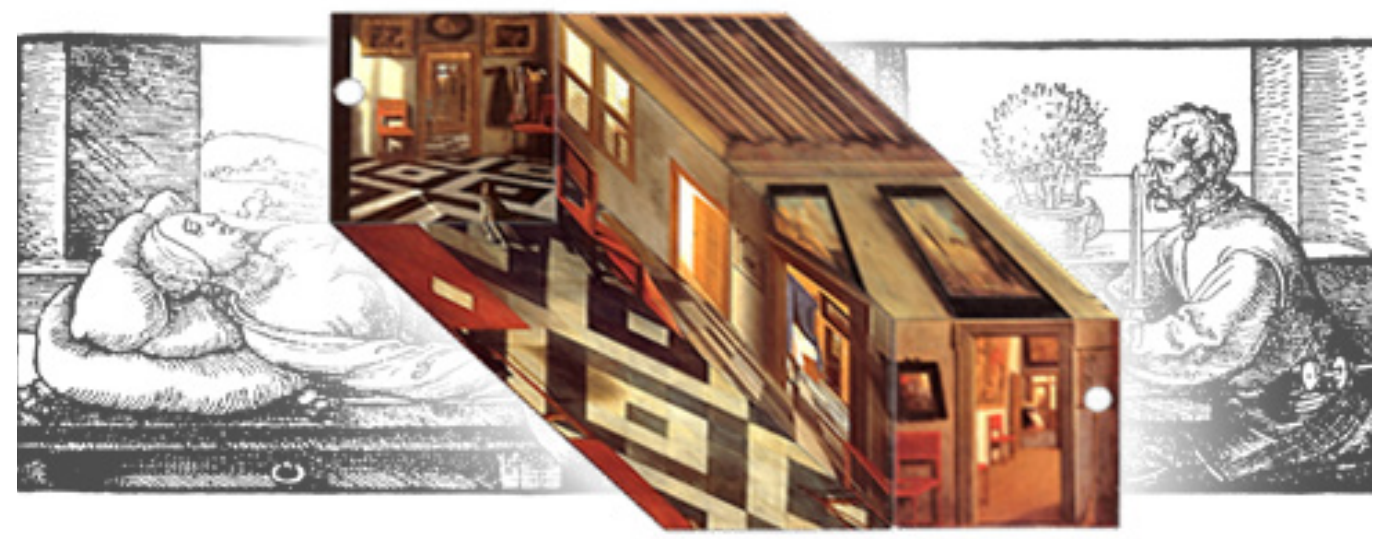




\section{A being-at-work theory: perspective objects and projective homologies 'in fact'}

It is right to claim -as Pavel Florenskij [1990] already did- that the advent of the Renaissance perspective has led to an impoverishment of the figurative spatiality, constraining it to a single monocular point of view. However, it would be extremely unfair to confuse the Renaissance perspective with the trompe-l'œil sideshow, ignoring the autonomy of the space figured in the perspective object, its expressive force and the virtual dynamics of the point of view that the artists have been able to render.

We are talking about a 'perspective object' -and not only about 'pictures' or 'flat images'first of all because we want to consider even the paintings in the whole and concrete practical and spatial scene of their concrete use, that is, in the way in which they establish a relationship between figurative space-time and time as it is actually experienced by the observer, a relationship that only rarely degenerates into trompe-l'œeil.The perspective object -namely, the two or three-dimensional perspective figuration with its place and use practices- is a visual artefact that evolves parallel to the mathematical theory of perspective, to the perspectival and optical devices, to the theatrical, domestic and liturgical spatiality, as well as to the anamorphic artefacts and their ostensive use in the Renaissance and Baroque wunderkammern.

The first assumption of our thesis is that, right from the early fifteenth century, the theory of linear perspective was born in its entirety at once, as a 'being-at-work geometry', both i) in its adequacy to account for visual phenomenology, and ii) in its geometric-projective coherence.

Fig. I. Three visualisations of the De prospectiva L. XXIX - Panizzi Library, Reggio Emilia, Mss. Regg. A $41 / 2$ [Piero 2017] -, in which Piero della Francesca exemplifies the geometric construction of the perspectival plan of an octagonal building: "Nel piano degradato la. superficie di un fondamente di un edifizio de octo face dato degradare". By "degradazione" " "deBy "degradazione ("degradation " the author perspective: a method perspective: a method of correct projective transformation of a flat figure (a square) starting from its true shape and from the observation distance a construction probably already in use in artistic practice: Leon Battista Alberti, Elementa picturae 1864]. It is shown how this construction presupposes the relationship poses the relationship identified by overtur be the point of the point of view on the plane of representation, transforming the perspective with centre in $\mathrm{O}$ on $\pi^{\prime}[\mathrm{O} \approx$ perspectivity centre; $\mathrm{O}^{*}$ $\approx$ homology centre in $\pi$; $\mathrm{O}^{\prime} \approx$ limit point; ' l' $^{\prime}$ limit line; $u \equiv u^{\prime} \approx$ axis of the homology] according to the two theorems by Simon Stevin [Stevin 1608, pp. 16-20].

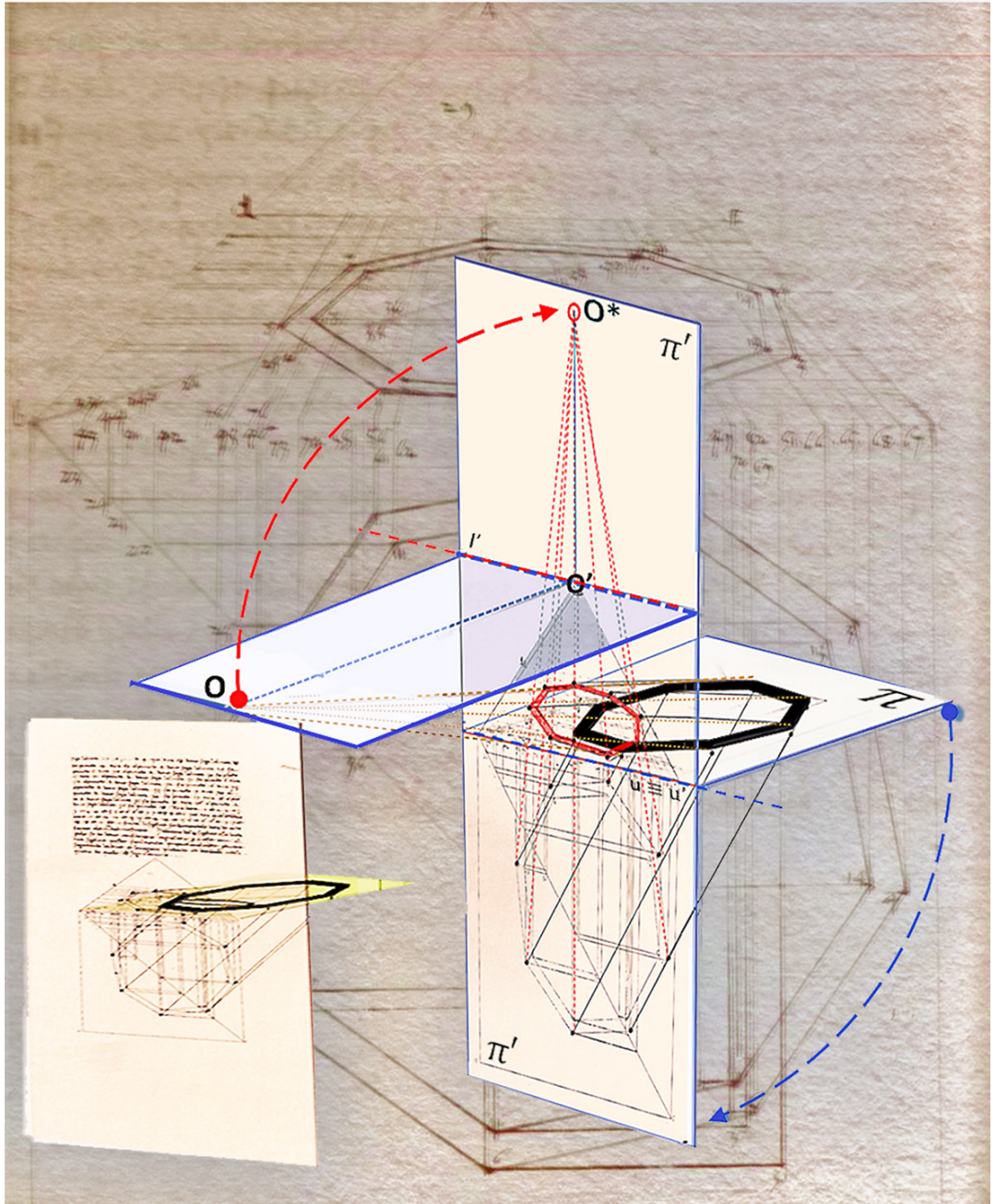


Fig. 2. a). Semiotic square of veridiction (here in the sense of "likelihood"): the "manifestation scheme is marked in red (not to seem $\leftrightarrow$ to seem) o seem $\leftrightarrow$ to seem) pp. 32 and 419$]$ pp. 32 and 419 . $M$. M. Hoch. at the centre, the axiology of the consumption values, in periphery, the axiology of valorisation modes of the spatial path of a traveller [Floch 1990]. i) The adequacy of the perspective to substitute the direct monocular vision had been demonstrated first of all through Brunelleschi's famous perspective tables which, by the second decade of the fifteenth century, were known both as works of art (high craftsmanship) and as prototypes of what we would now call 'scientific demonstrations'.

ii) In the following half century, the full internal coherence of the perspective drawing was achieved, in relation to the fact that -as evidently shown in its first explanatory drawings (fig. I) - its construction depended on the transformation of simple flat figures, that is, on the tracing of what we would now call 'flat perspectivities on the picture plane', namely on 'homologies of the plane', although we cannot make explicit use of the concept of 'homology centre', but only of limit elements (vanishing points and lines) and joined elements.

The idea that the centre of the constructive homology of the perspective of a polygon was nothing but its 'point of view' overturned on the picture plane around the trace of a projecting plane (fig. I) was already contained in an embryonic form in Alberti's 'abbreviated construction' and was completely clarified by Simon Stevin [ 1605] in the form of a theorem. Stevin's theorem takes us back to the historical observation that especially in the Flemish and Dutch environment [Wheelock 1973] and mainly in the genre of the 17th century interior view, perspective theory evolves by intertwining its three aspects: optical adequacy, geometric consistency and invention of new visual artefacts. We refer to the 'perspective boxes', known today through six specimens that are the size of a piece of furniture -just a little smaller than the similar, and typical, painted 'marriage chests'- as if they were models of domestic scenes.

Hybrid objects between panel painting and perspective in relief, these 'boxes' composed of pictorial tables are coherent 'perspectives of perspectives' that anamorphically show an interior on the faces of a prism but with a luminous and atmospheric likelihood never achieved before in painting. They impose the evidence of this 'atmospheric' likelihood, making it further experienced since it offers a spectator in motion the spectacle of a (figured) interior in a (real) interior, namely under analogue lighting conditions and within physically comparable semantic frames.
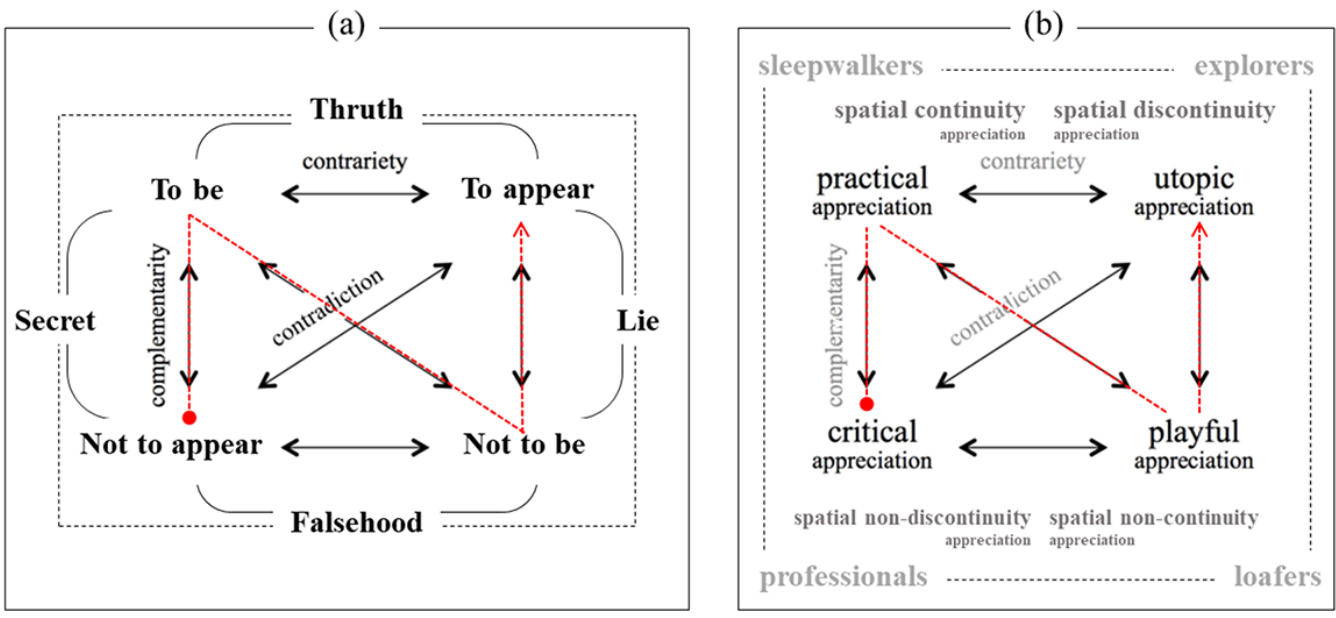

The cognitive paths of the spectator and the painter: stage of perspectivity and stage of perspective

These [meta]perspective Dutch furnishing objects - belonging to the genealogy of Renaissance and Baroque anamorphoses- lend themselves to the classic use pattern of the anamorphoses, which takes into account different spatial positions of the observer's point of view: some of them are 'correct' or 'deceptive', others are progressively deformed, 'in accommodation' or 'in adjustment'. These values of 'correctness' or 'deception', 'randomness' or 'necessity' depend on the plausible semantic frames of the concrete scene of use of the anamorphic object. 
a) Spectator's path - The extensive historiography on the anamorphic quadratura agrees at least on the processuality of the spectacle of the emergence and disappearance of the shapes in the perception of an observer covering its possible paths; moreover, it mostly gives this process the meaning of a progressive awareness of the spectator, according to a cathartic or, at times, pedagogical aim.

In the case of the Dutch perspective boxes representing domestic interiors, we can simplify this scheme by first distinguishing the two (typical) opposite stages:

$1^{\circ}$ ) the (lasting) one in which the viewer sees the piece of furniture as such, grasping some form of coherently 'distorted' pictorial representation,

$2^{\circ}$ ) the (perfective) one in which the viewer, located in the 'correct' points of view, enjoys a phenomenally probable (deceptive) view of the represented interior.

Fig. 3. Representation through orthogonal projections and flat net of a cubic box OUXYZ with the $\pi$ ' image projected from $O$ on the tri-rectangular trihedron UXYZ $\mathrm{O} \approx$ Centre of the three perspectivities between $\pi$ and $U X Y, \pi^{\prime}$ and $U X Z, \pi^{\prime}$ and $U Y Z ; d \approx$ main distance; $\pi \approx$ parallel anterior plane: $X * Y * Z * \approx$ flat net of UXYZ; $\left(\pi^{\prime} \cup X Y Z\right)^{*} \approx$ net of the trilateral joined in the perspectivities. See fig 8 for examples of construction.

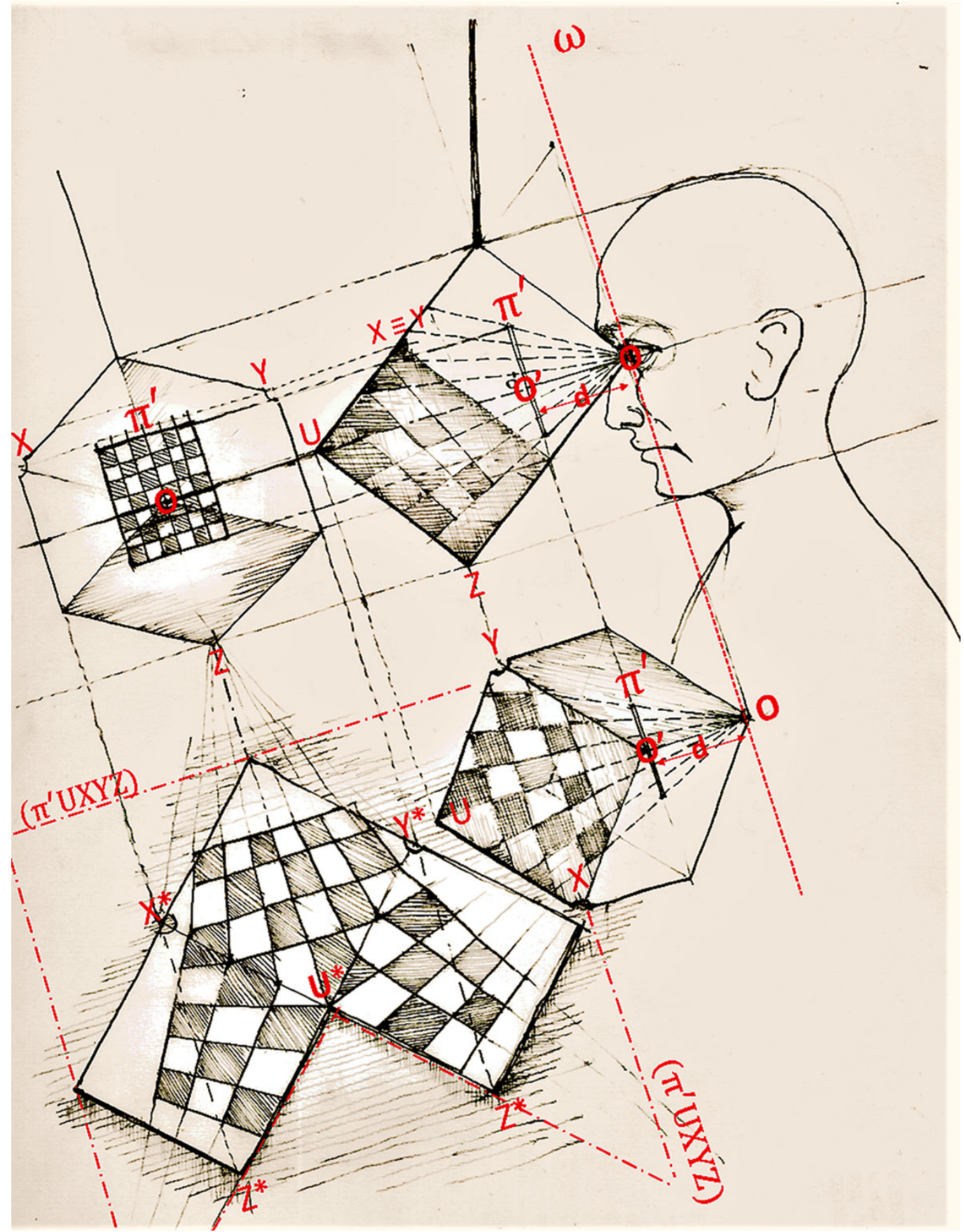


Fig. 4. Perspective box

on panels, $84 \times 82 \times 42$

Cm, (c. 1660-80), Den

a) reconstruction of

the paradoxical starting

image with indication of

the circle of distance;

b) flat net of the three

internal faces:

c) superimposition of

the starting image on

the box;

d) perspective box in

orthogonal axonometry;

e) referent interior.

Fig. 5. Perspective box by Samuel van Hoogstrate, oll on panels, $58 \times 88$

$\times 60.5 \mathrm{~cm}$, (c. 1655-60),

London, National Gallery:

a) isometric orthogonal

unfolded axonometry

the external faces;

b) unfolded axonometry

of the internal faces

c) reconstruction of

one of the paradoxical

starting images for the

front view.
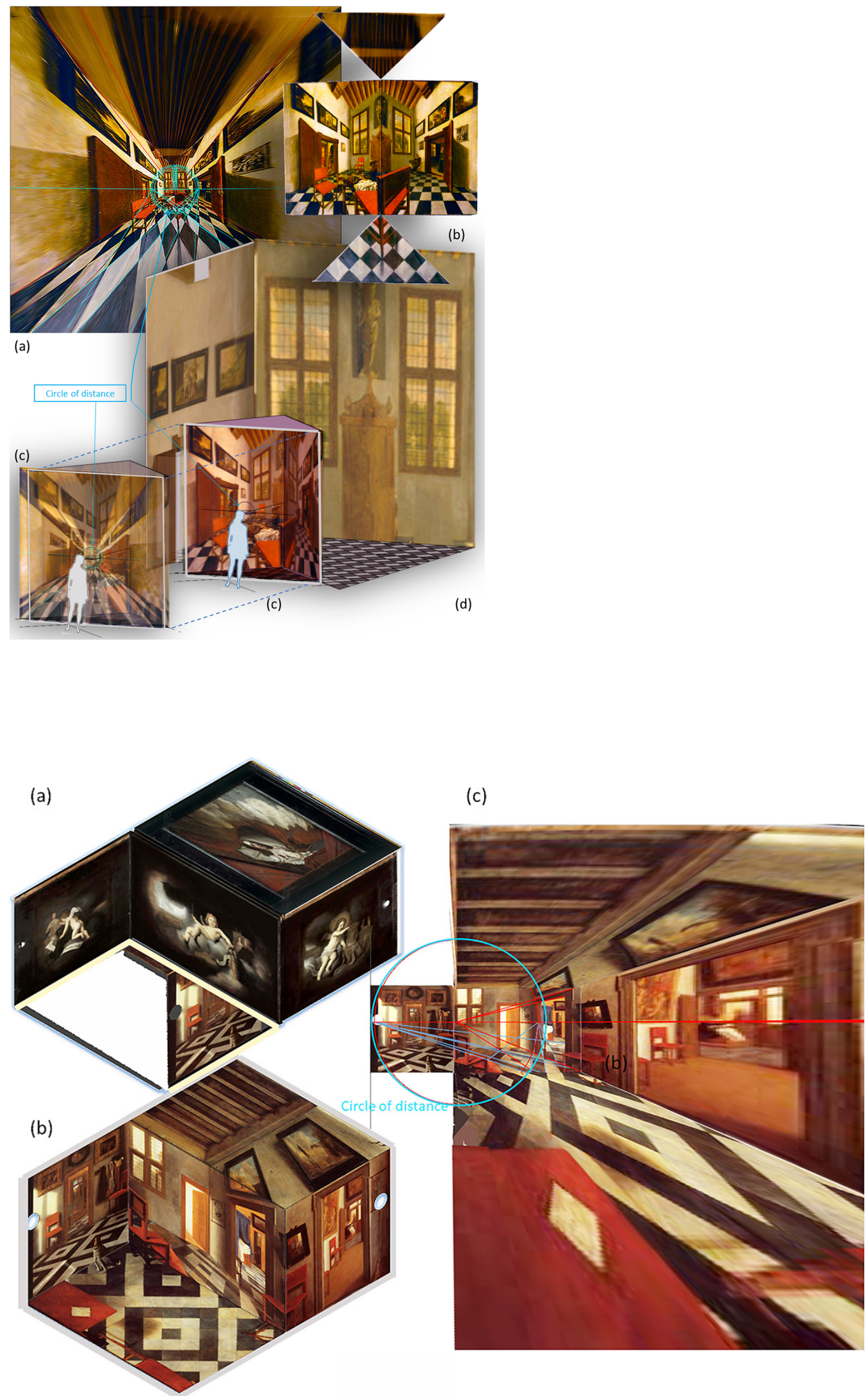
We define the first stage as that of 'perspectivity' since the viewer sees, in a binocular way, the painting on each face of the box as deformed and autonomous, not collimating with the others. In this condition, the possible representative content of the paintings is confined to a virtual existence with respect to the concrete reference space. It is only when the viewer, watching with only one eye placed in the designated position, comes to grasp the visual collimation between different paintings, that he enters the second cognitive stage: that of the real 'perspective'. It is only in that moment that the spectator -due to the forcedly placed and exclusively monocular position- realises the (deceptive) show of the figured interior and confines the 'real' space to a 'virtual' existence with respect to the visually experienced space, since there is now a discrepancy between the 'optical space' and the other sensory spaces in the spectator's consciousness, as Florensky would say [Florensky 2007, pp. 27I-273].

The essential of the typical spectacle offered by these devices can be summarised by considering two classical schemes of the semiotic theory of Greimassian tradition. They show that (fig. 2a) in the lasting phase (I) the anamorphic object is judged as the bearer of a 'secret' that leads to the 'concrete' and 'distorted' representation of an interior, a representation that turns out to be 'illusory' and, finally, 'likely' in the deceptive phase (2), demonstrating its
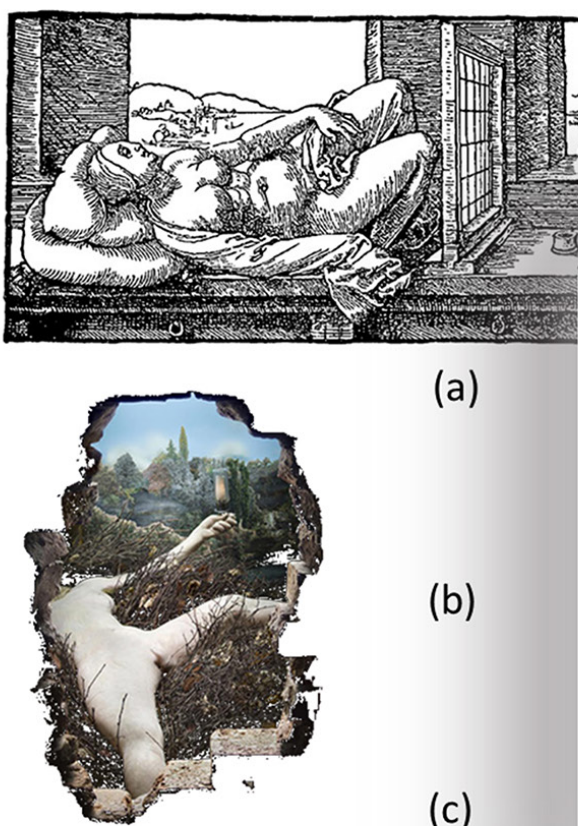

(a)
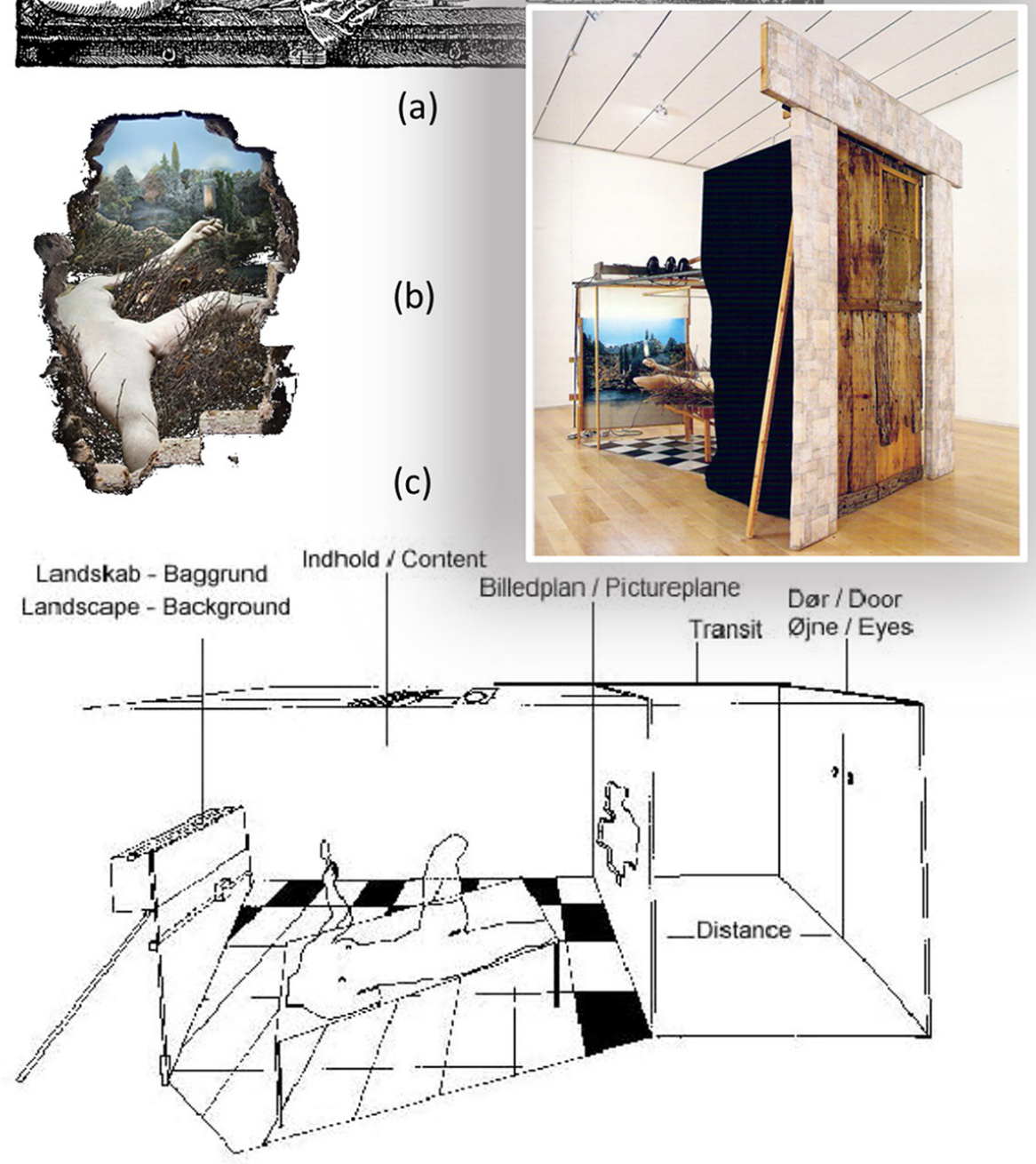

(c)

(b)

c)

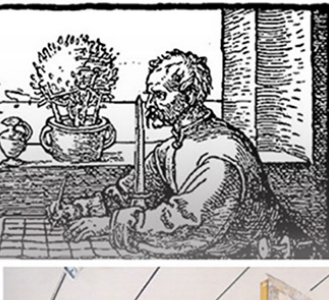


'truth' in relation to a virtual reference space. In the process of accommodation of the point of view, the space of the real interior can be differently valorised (fig. 2b) transforming the attitudes and role of the spectator who shifts from the (critical) exploration of the real space to the (participatory) exploration of the represented virtual space. The semiotic square neatly represents the cyclical nature of these processes that are somehow analogous to a 'hysteresis' phenomenon.

b) Path of the painter - Most probably, the construction of a perspective box presupposes a typical anamorphic quadratura technique (fig. 3): it starts from an overall perspective drawing and comes to its projection on at least three distinct faces, that is, at least three 'perspectivities' of the same 'perspective'. The geometric conditions for a correct construction are two: $1^{\circ}$ ) the consistency of the perspectivities and $2^{\circ}$ ) the likelihood of the perspective depth rendering [White 197I] by adopting a 'main distance' compatible with that of the obliged point of view.

The initial perspective is a de facto 'paradoxical' view since it falls almost totally outside the correct circle of distance according to the designated point of view (figs. 4, 5).

In practice, the projection of this first drawing could phisically take place, by following the shadow of a grid made of threads - similar to that of the preparatory drawing- projected on the faces of the box by a light placed in the sole centre of all the different perspectivities. However, this practical procedure is only feasible when the point of view is, even if only slightly, outside the box (fig. 4).
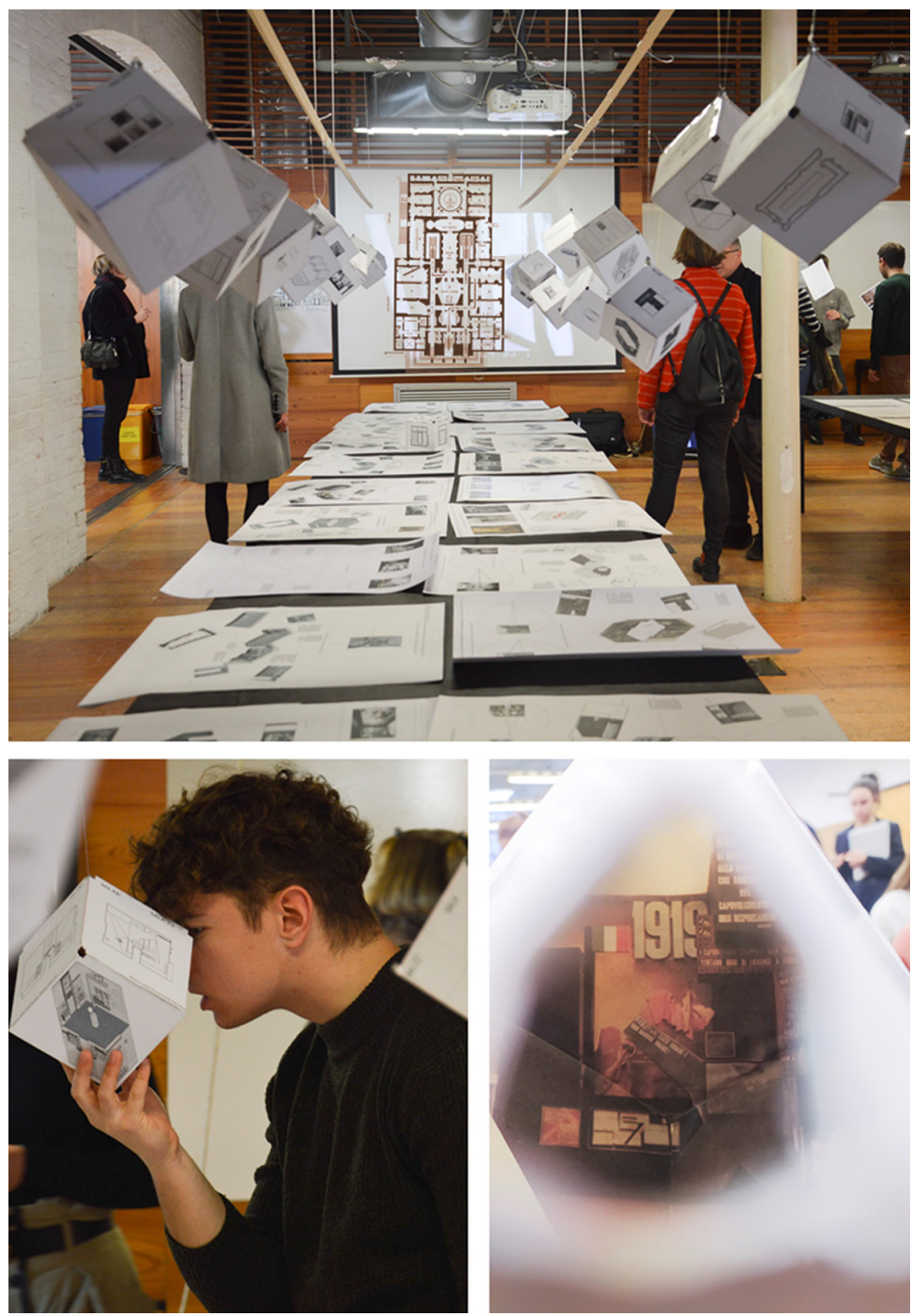
(a)

Fig. 8. One of the perspective boxes displayed at the exhibition L'interno tra le arti (the interior between the arts).

a) Axonometric study of

the interior shown;
b) net of the outer faces

of the box;

c) net of the inner faces of the box and one of the views.

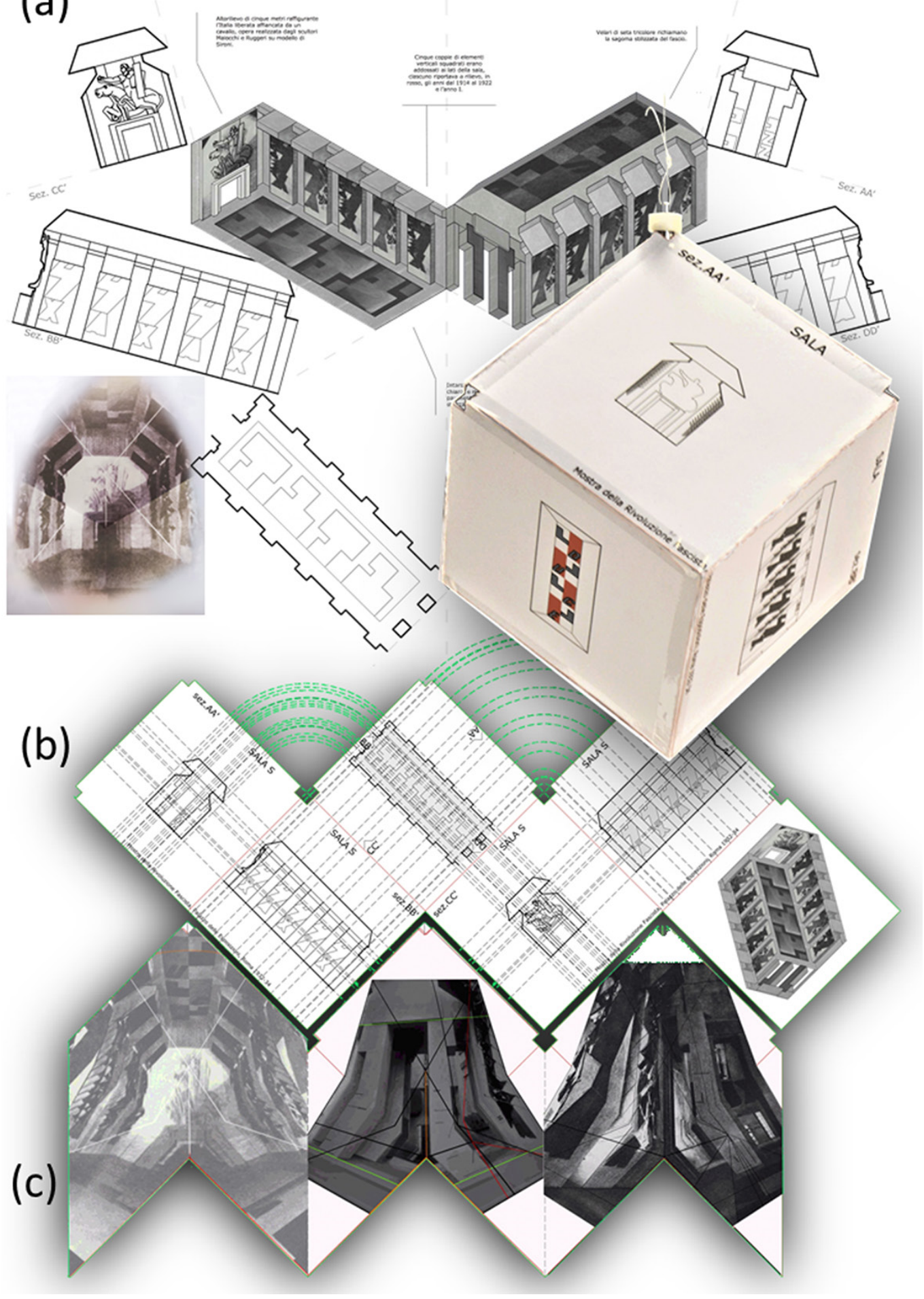



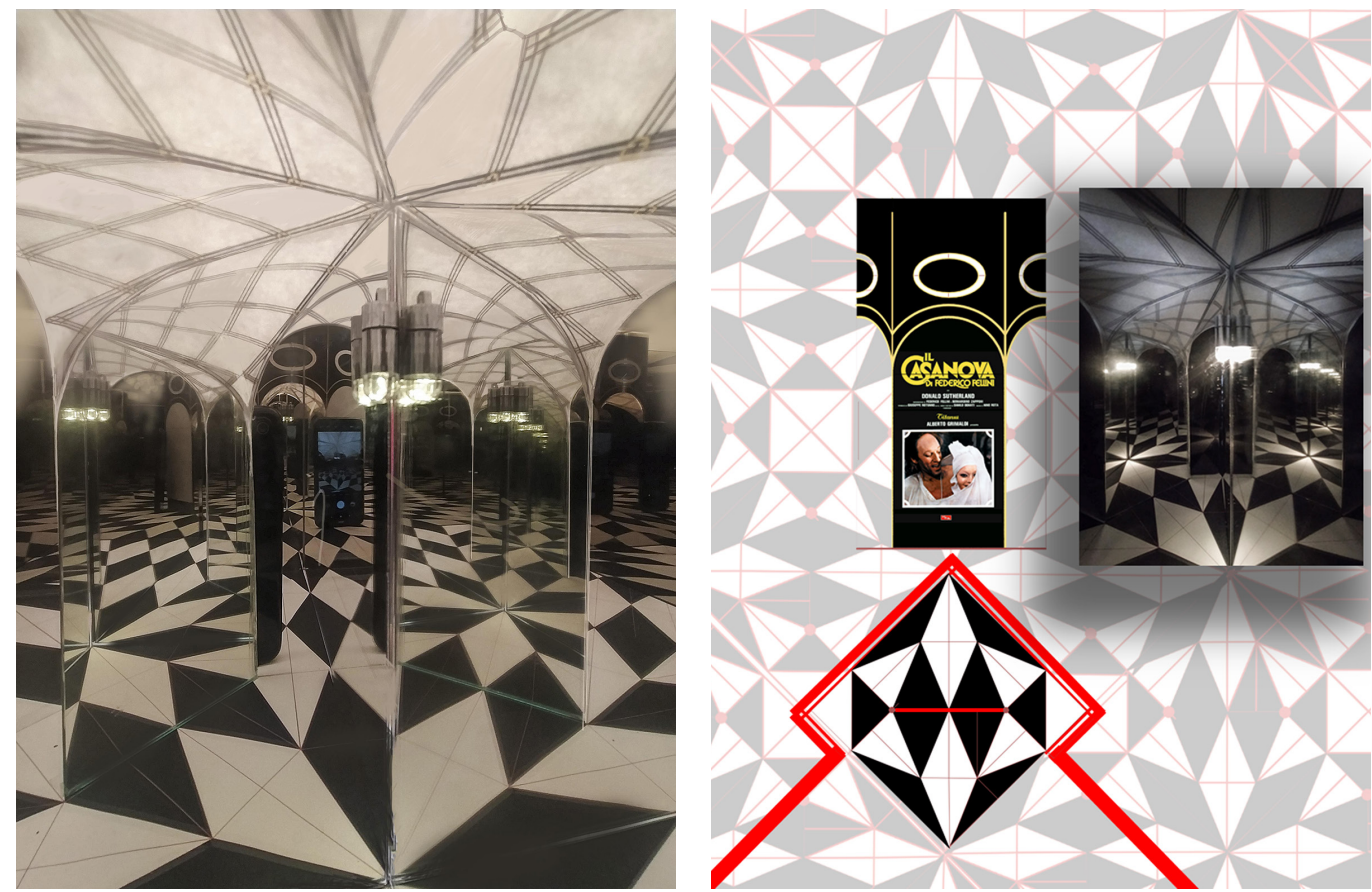

At least one case -among the six known today- (fig. 5) only partially fulfils this condition, since two of the three points of 'correct view' designed by van Hoogstraten exceed the 'main distance' adopted in the perspective construction of their views. David Bomford [Bomford et al. 1987] believes that the construction of the perspectival coordination of the views took place empirically, given the fact-Joyce Plesters' observation [Brown et al. 1 987] is right- that van Hoogstraten did not explain it in his posthumous treatise published in 1678 [Hoogstraten 1969].

Anyway, there are some hypotheses that have not been examined yet, in relation to the integration of van Hoogstraten's box, preserved in the National Gallery, with appropriate catoptric devices capable of placing the point of view in a perspective object that is made to de-automate the daily vision by playing on a phenomenon of estrangement and re-assimilation of the observer.

In any case, it seems that the path of the painter and the one of the observers -from the stage of perspectivity to that of perspective- coincide but follow opposite directions.

\section{The 'motive' of the interior gaze}

A part of the literature on the iconographic interpretation of the Dutch views of domestic interiors identifies its 'topic' in the narration of domestic events in the form of a short screenplay of stereotyped situations. However, the external faces of the perspective boxes sometimes add an allegorical guise that complicates the attribution of semantic properties to some figured objects.

This convergence of 'allegory' and 'spied interior' highlights the 'motif' of 'seduction' and the 'erotic' isotopy -frequent in the Dutch paintings of the seventeenth century [Koslow 1967; Woodall 1996] - which gives the thematic role of the voyeur to the viewer (fig. 2 b).

This -according to some studies such as those by Susan Koslow [Koslow 1967]- seems clear in the aforementioned National Gallery box, whose interior representations show scattered objects such as a pillow, a comb, a pearl necklace, which lead to a woman probably seduced by her visitor. Herman Colenbrander [Colenbrander 20 I3], instead, compares that box to the other three that represent domestic interiors and concludes that the two moral themes of vanitas and choice between vice and virtue are mainly present. Moreover, those 


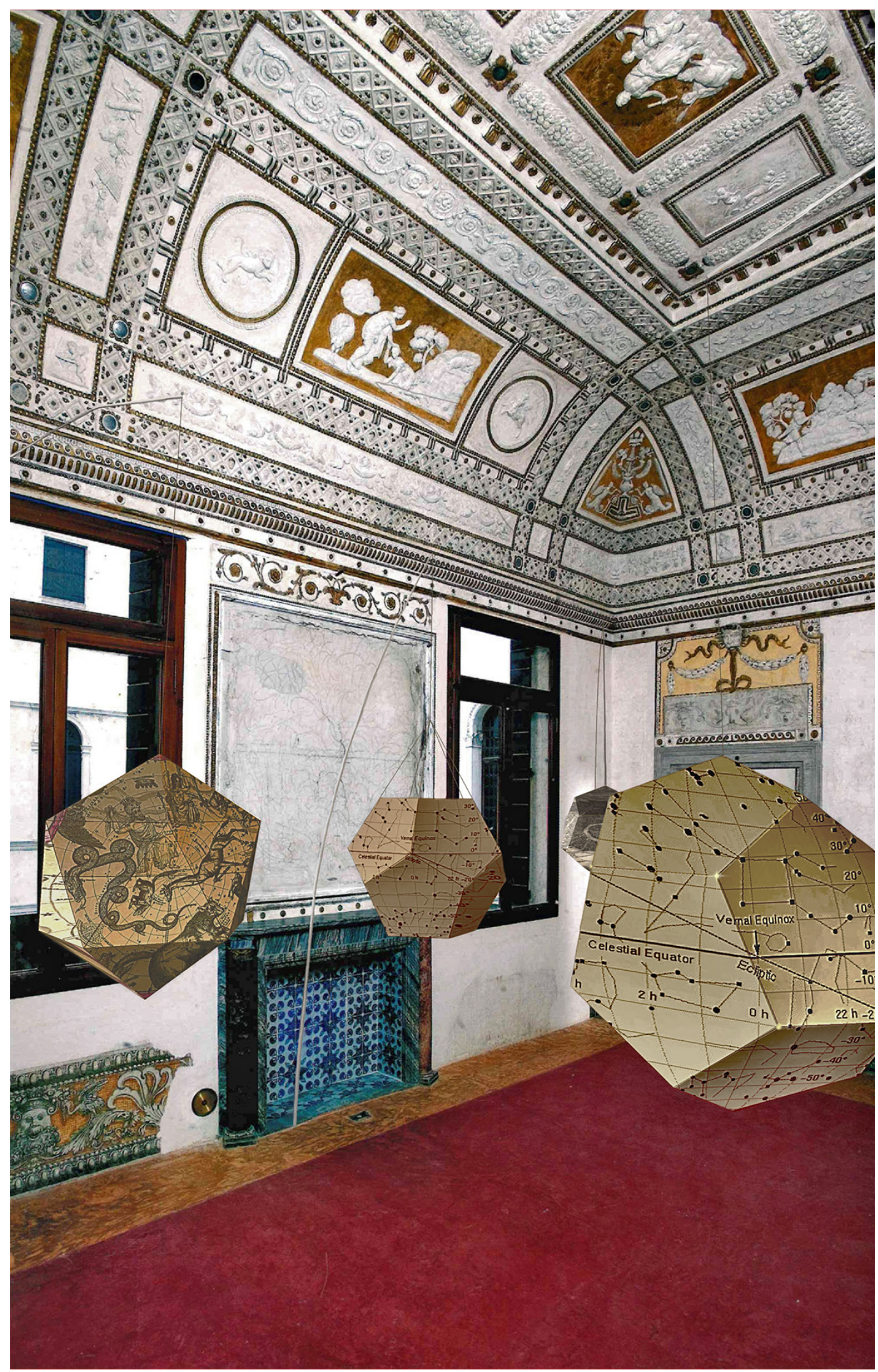


still-life representations with modest breakfasts were often part of wedding gifts, so, once again, this would lead us to think of marriage chests. Celeste Brusati [Brusati 1995; Brusati 20 I3], however, after having recognised the substantial presence of the erotic element, still favours the importance that the box should have had in showing the results achieved in the construction of perspectives. In particular, the simulated frames, present in many works by van Hoogstraten, are a fundamental element, being the expression of the duality of the painting, on the one hand a material object, on the other hand a representation: precisely, a 'representation of a representation' that works according to the cycle that we have indicated (fig. 2).

Therefore, (perspective or catoptric) projective boxes are visual artefacts belonging to the genealogy that spans the various forms of peepshow and their contemporary artistic reinventions: for example, from the installation that Marcel Duchap entitled Étant Donnés: $1{ }^{\circ}$ la chute d'eau, $2^{\circ}$ le gaz d'éclairage... (fig. 6) to the film Paris, Texas by Wim Wenders.

\section{Practical conclusions: three of the modes of the interior in interior}

(Perspective and catoptric) projective boxes are 'multifaceted' objects also from a semantic point of view. In order to study some aspects of their semantic 'facet', we have designed other boxes meant for typical situations in contemporary displaying, by recognising what we have called 'the motive of the gaze' according to the aforementioned (fig. 2 b) axiologies by Floch.

a) Critical and practical valorisation: a didactic device.

On the occasion of the exhibition of an exhibition (fig. 7) - the didactic exhibition of a graphic study concerning the Fascist Revolution Exhibition at the Palazzo delle Esposizioni in Rome in 1932-1934 - we designed a series of cubic perspective boxes each of which, coupled with a printed analytical diagram, shows the reconstruction through photomodelling of a room in the exhibition. On the external faces of each cube (fig. 8) the representations of a room are placed in orthogonal projection according to the actual reciprocal position of the representation planes (fig. 8a). On the internal faces, visible from the holes in the three upper vertices, the historical photographs used in the reconstruction are anamorphically printed (fig. 8b). The construction of the anamorphosis took into account the internal orientation calculated on the photo; besides, the viewing hole is located exactly in the focal centre of the original photograph. Therefore, the monocular view of the interior is fully deceptive, we would say, in 'virtual reality', no matter if the object is made of paper, internally lit by a led. b) Ludic valorisation: a kaleidoscopic compulsion angle.

With a kaleidoscope physically traversable by the spectator (figs. 9, 10) set up in a Murano garden we have tried to restore the dreamlike atmosphere of an octagonal set of Fellini's Casanova (1976): the scene of the meeting between the seducer and the nun Maddalena on the Venetian island of San Bartolo, pleased to be spied by Abbot de Bernis through a hole hidden in the eye of a fish painted on the wall of the alcove. Obviously, this set is part of the varied genealogy of peepshows and, by translating it from cinema to a catoptric box, some sense effects become amplified (fig. 10).

c) Mythical valorisation: allegories in search of subjects.

In the sixteenth-century Room of Callisto, located inside Palazzo Grimani in Venice (fig. I I), we proposed a variation on the theme of Duchamp's Étant Donnés. These are double-sided Platonic polyhedra made of paper, marked by historical graphic images: on the external faces there are maps of the zodiacal constellations and topographical views topologically adapted to the polyhedron; inside there are erotic engravings derived from I Modi published by Marcantonio Raimondi from 1524, correctly visible - since they are projectively adapted - through peepholes placed in some vertices. These images of opposite spaces interact with the astrological and mythological themes of the ceiling decoration, but they create an iconographic short-circuit between genres considered high and low, following the ironic frame marked by a coeval ode by Francesco Berni (fig. 12). 


\section{XI}

\section{CAPITOLO DELL'ORINALE}

Chi non ha molto ben del naturale et un gran pezzo di conoscimento

3 non può saper che cosa è l'orinale, né quante cose vi si faccin drento (dico senza il servigio dell'orina),

6 che sono ad ogni modo presso a cento; e se fusse un dottor di medicina che le volesse tutte quante dire,

9 arìa facende insino a domattina. Pur, chi qual cosa ne volesse udire, io son contento, per fargli piacere,

12 tutto quel ch'io ne so di diffinire.

E prima inanzi tratto è da sapere che l'orinale è a quel modo tondo

15 acciò che possa più cose tenere: è fatto proprio come è fatto il mondo, che, per aver la forma circulare,

18 voglion dir che non ha né fin né fondo; questo lo sa ogniun che sa murare e che s'intende dell'architettura che insegna altrui le cose misurare. Ha gran profondità la sua natura, 


\section{References}

Alberti Leon Battista (I 864). Gli elementi di pittura. Cortona: Bimbi. Trad. dal manoscritto originale latino [1 435-'6] Elementa picture. Biblioteca statale di Lucca, ms. 1448.

Berni Francesco (2002). Rime. Milano: Mursia.

Brown Christopher et al. (1987). Samuel van Hoogstraten: Perspective and Painting. In National Gallery Technical Bulletin, vol. II, pp. 60-85.

Brusati Celeste (1995). Artifice and Illusion: The Art and Writing of Samuel Van Hoogstraten. Chicago; London:The University of Chicago Press.

Brusati Celeste (2013). Paradoxical Passages:The Work of Framing in the Art of Samuel van Hoogstraten. In Thijs Weststeijn. Universal Art of Samuel van Hoogstraten (1627-1 678). Amsterdam: Amsterdam University Press, pp. 53-76.

Colenbrander Herman (20 I3). A Pledge of Marital Domestic Bliss: Samuel van Hoogstraten's Perspective Box in the National Gallery, London. In Thijs Weststeijn. Universal Art of Samuel van Hoogstraten (I 627- I678). Amsterdam: Amsterdam University Press, pp. I39-159.

Dürer Albrecht (1525). Unterweisung der Messung mit dem Zirkel und Richtscheit in Linien, Ebenen und ganzen Corporen. Nürnberg: H. Andreae.

Floch Jean-Marie (1990). Sémiotique, marketing et communication: sous les signes, les stratégies. Paris: Presses Universitaires de France.

Florenskij Pavel Aleksandrovič (1990). La prospettiva rovesciata. Roma: Gangemi Editore.

Florenskij Pavel Aleksandrovič (2007). Lo spazio e il tempo nell'arte. Milano: Adelphi.

Greimas Algirdas Julien, Courtés Joseph (1979). Sémiotique: dictionnaire raisonné de la théorie du langage. Tome I. Paris: Classiques Hachette.

Hoogstraten Samuel van (1969) [1674]. Inleyding tot de hooge schoole der schilderkonst. Utrecht: Dawaco.

Koslow Susan (1967). De Wonderlijke Perspectyfkas: An Aspect of Seventeenth Century Dutch Painting. In Oud-Holland, 82, pp. 35-56.

Lyotard Jean-Francois (2010) [1977]. Les Transformateurs Duchamp = Duchamp's TRANS/Formers. Leuven: Leuven University Press.

Della Francesca Piero (2017) [1472]. De Prospectiva pingendi. Roma: Istituto Poligrafico e Zecca dello Stato.

Stevin Simon (1605). Wisconstige gedachtenissen: inhoudende t'ghene daer hem in gheoeffent heeft den ... Maurits, Prince van Oraengien .... [online]. Tot Leyden: Inde druckerye van lan Bouwensz. (c) $2010 \mathrm{dbnl}$. <https://www.dbnl.org/tekst/ stev00 I wisc03_0l/stev00/wisc03_0l.pdf>.

Wheelock Arthur K. (1973). Carel Fabritius: Perspective and Optics in Delft. In Nederlands kunsthistorisch jaarboek / red. A.W. Byvanck [u.a.], 24, pp. 63-83.

White John (197I). Nascita e rinascita dello spazio pittorico. Milano: il Saggiatore.

Woodall Joanna (1996). Love Is in the Air - «Amor» as Motivation and Message in Seventeenth-Century Netherlandish Painting. In Art History, 2, 19, pp. 208-246.

\section{Authors}

Fabrizio Gay, Università IUAV di Venezia, degli Studi di Napoli Federico II, fabrizio@iuav.it Irene Cazzaro,Alma Mater Studiorum Università di Bologna, irene.cazzaro2@unibo.it

To cite this chapter: Gay Fabrizio, Cazzaro Irene (2020). Connettere spazi tra arti e scienze: scatole proiettive come realtà (analogicamente) aumentata prima e dopo la Realtà (digitalmente) Aumentata/Connecting spaces between art and science: projective boxes as (analogical) augmented reality before and after the (digital) Augmented Reality. In Arena A., Arena M., Brandolino R.G., Colistra D., Ginex G., Mediati D. Nucifora S., Raffa P. (a cura di). Connettere. Un disegno per annodare e tessere. Atti del $42^{\circ}$ Convegno Internazionale dei Docenti delle Discipline della Rappresentazione/Connecting. Drawing for weaving relationships. Proceedings of the 42 th International Conference of Representation Disciplines Teachers. Milano: FrancoAngeli, pp. 485-510. 